\title{
Sensitivity of wetland methane emissions to model assumptions: application and model testing against site observations
}

\author{
L. Meng ${ }^{1}$, P. G. M. Hess ${ }^{2}$, N. M. Mahowald ${ }^{3}$, J. B. Yavitt ${ }^{4}$, W. J. Riley ${ }^{5}$, Z. M. Subin ${ }^{5}$, D. M. Lawrence ${ }^{6}$, \\ S. C. Swenson ${ }^{6}$, J. Jauhiainen ${ }^{7}$, and D. R. Fuka ${ }^{2}$ \\ ${ }^{1}$ Department of Geography and Environmental Studies Program, Western Michigan University, Kalamazoo, MI 49008, USA \\ ${ }^{2}$ Department of Biological and Environmental Engineering, Cornell University, Ithaca, NY 14850, USA \\ ${ }^{3}$ Department of Earth and Atmospheric Sciences, Cornell University, Ithaca, NY 14850, USA \\ ${ }^{4}$ Department of Natural Resources, Cornell University, Ithaca, NY 14850, USA \\ ${ }^{5}$ Earth Sciences Division, Lawrence Berkeley National Laboratory, Berkeley CA 94720, USA \\ ${ }^{6}$ NCAR-CGD, P.O. Box 3000, Boulder, CO 80307, USA \\ ${ }^{7}$ Department of Forest Sciences, P.O. Box 27, University of Helsinki, Helsinki 00014, Finland
}

Correspondence to: L. Meng (lei.meng@wmich.edu)

Received: 14 June 2011 - Published in Biogeosciences Discuss.: 30 June 2011

Revised: 13 June 2012 - Accepted: 29 June 2012 - Published: 30 July 2012

\begin{abstract}
Methane emissions from natural wetlands and rice paddies constitute a large proportion of atmospheric methane, but the magnitude and year-to-year variation of these methane sources are still unpredictable. Here we describe and evaluate the integration of a methane biogeochemical model (CLM4Me; Riley et al., 2011) into the Community Land Model 4.0 (CLM4CN) in order to better explain spatial and temporal variations in methane emissions. We test new functions for soil $\mathrm{pH}$ and redox potential that impact microbial methane production in soils. We also constrain aerenchyma in plants in always-inundated areas in order to better represent wetland vegetation. Satellite inundated fraction is explicitly prescribed in the model, because there are large differences between simulated fractional inundation and satellite observations, and thus we do not use CLM4-simulated hydrology to predict inundated areas. A rice paddy module is also incorporated into the model, where the fraction of land used for rice production is explicitly prescribed. The model is evaluated at the site level with vegetation cover and water table prescribed from measurements. Explicit site level evaluations of simulated methane emissions are quite different than evaluating the grid-cell averaged emissions against available measurements. Using a baseline set of parameter values, our model-estimated average global wetland emissions for the period 1993-2004 were $256 \mathrm{Tg} \mathrm{CH}_{4} \mathrm{yr}^{-1}$ (including the soil sink) and rice paddy emissions in the year 2000 were $42 \mathrm{TgCH}_{4} \mathrm{yr}^{-1}$. Tropical
\end{abstract}

wetlands contributed $201 \mathrm{TgCH}_{4} \mathrm{yr}^{-1}$, or $78 \%$ of the global wetland flux. Northern latitude $(>50 \mathrm{~N}$ ) systems contributed $12 \mathrm{Tg} \mathrm{CH}_{4} \mathrm{yr}^{-1}$. However, sensitivity studies show a large range $\left(150-346 \mathrm{Tg} \mathrm{CH}_{4} \mathrm{yr}^{-1}\right)$ in predicted global methane emissions (excluding emissions from rice paddies). The large range is sensitive to (1) the amount of methane transported through aerenchyma, (2) soil $\mathrm{pH}\left( \pm 100 \mathrm{TgCH}_{4} \mathrm{yr}^{-1}\right)$, and (3) redox inhibition $\left( \pm 45 \mathrm{Tg} \mathrm{CH}_{4} \mathrm{yr}^{-1}\right)$. Results are sensitive to biases in the CLMCN and to errors in the satellite inundation fraction. In particular, the high latitude methane emission estimate may be biased low due to both underestimates in the high-latitude inundated area captured by satellites and unrealistically low high-latitude productivity and soil carbon predicted by CLM4.

\section{Introduction}

Methane $\left(\mathrm{CH}_{4}\right)$ is an important greenhouse gas and has made a $\sim 12-15 \%$ contribution to global warming (IPCC, 2007). Its atmospheric concentration has increased continuously since 1800 (Chappellaz et al., 1997; Etheridge et al., 1998; Rigby et al., 2008) with a relatively short period of decreases during 1999-2002 (Dlugokencky et al., 2003). Wetlands are the single largest source of atmospheric $\mathrm{CH}_{4}$, although their estimated emissions vary from 80 to $260 \mathrm{Tg} \mathrm{CH}_{4}$ annually (Bartlett et al., 1990; Matthews and 
Fung, 1987; Whalen, 2005; Hein et al., 1997; Walter et al., 2001; Chen and Prinn, 2006; Mikaloff Fletcher et al., 2004; Bousquet et al., 2006; Spahni et al., 2011). In addition, the spatial distribution of methane emissions from wetlands is still unclear. For instance, some recent studies suggest that tropical regions $(20 \mathrm{~N}-30 \mathrm{~S})$ release more than $60 \%$ of the total wetland emissions (Bergamaschi et al., 2007; Chen and Prinn, 2006; Frankenberg et al., 2006), whereas other studies argue that northern wetlands contribute as much as $60 \%$ of the total emissions (Matthews and Fung, 1987). For tropical regions, methane emissions are highly uncertain because (1) tropical wetlands have a large area that fluctuates seasonally (Aselmann and Crutzen, 1989; Matthews and Fung, 1987; Page et al., 2011) and (2) methane fluxes vary significantly across different wetland types (Nahlik and Mitsch, 2011). Rice paddies are human-made wetlands and are one of the largest anthropogenic sources of atmospheric methane. Methane emission rates from rice paddies have been estimated to be 20 to $120 \mathrm{Tg} \mathrm{CH}_{4} \mathrm{yr}^{-1}$ (Yan et al., 2009) with an average of $60 \mathrm{TgCH}_{4} \mathrm{yr}^{-1}$ (Denman et al., 2007; Wuebbles and Hayhoe, 2002). Together, previous modeling studies suggest rice paddies and wetlands can release 100 $380 \mathrm{Tg} \mathrm{CH}_{4} \mathrm{yr}^{-1}$ to the atmosphere. Further, recent studies identified a new source of tropical methane from nonwetland plants that could add as much as $10-60 \mathrm{Tg} \mathrm{CH}_{4} \mathrm{yr}^{-1}$ to the global budget (Keppler et al., 2006; Kirschbaum et al., 2006), although this source has been disputed and is still poorly quantified (Dueck et al., 2007).

Process-based methane emission models have been previously used to estimate the global methane budget (Zhuang et al., 2004; Walter et al., 2001; Potter, 1997; Christensen et al., 1996; Wania et al., 2010; Cao et al., 1996). Due to the complexity of wetland systems and the paucity of field and laboratory measurements to constrain process representations, these models used different approaches to simulate the methane emissions. Zhuang et al. (2004) coupled a methane module to a process-based biogeochemistry model, the Terrestrial Ecosystem Model (TEM), with explicit calculation of methane production, oxidation, and transport in the soil and to the atmosphere. Walter et al. (2001) integrated a processbased methane model with a simple hydrologic model to estimate methane emissions from wetlands with external forcing of net primary production. Cao et al. (1996) developed a methane model based on substrate supply by plant primary production and organic matter degradation. The most recent methane model developed by Wania et al. (2010) is fully coupled into a global dynamic vegetation model designed specifically to simulate northern peatlands. This model uses a mechanistic approach with some empirical relationships and parameters to simulate peatland hydrology. As discussed above, these models parameterize the biogeochemical processes and hydrological processes in different ways and use different inputs (e.g., inundated area and NPP). Thus, it is not surprising that they produce a large range of emissions for the global methane budget. For instance, Cao et al. (1996) estimated the global methane emissions from wetlands to be $92 \mathrm{TgCH}_{4} \mathrm{yr}^{-1}$, while Walter et al. (2001) calculated an emission of $260 \mathrm{Tg} \mathrm{CH}_{4} \mathrm{yr}^{-1}$ from global wetlands. This large range indicates a high degree of uncertainty in the global methane budget.

Here, we modify and apply a process-based methane model (CLM4Me, Riley et al., 2011) that simulates the physical and biogeochemical processes regulating terrestrial methane fluxes and is integrated in the Community Earth System Model (CESM1.0) so that feedbacks between methane and other processes can be simulated. Specifically, CLM4Me includes physical and biogeochemical processes related to soil, hydrology, microbes and vegetation that account for microbial methane production, methane oxidation, methane and oxygen transport through aerenchyma of wetland plants, ebullition, and methane and oxygen diffusion through soil. The integration of processes into CLM4CN (called CLM4Me) has been described in detail by Riley et al. (2011). Although CLM4Me can be operated as part of a fully-coupled carbon-climate-chemistry model, here we force the global methane emission model with the best available information for the current climate, including satellite-derived inundation fraction (Prigent et al., 2007; Papa et al., 2010), rice paddy fraction (Portmann et al., 2010), soil $\mathrm{pH}$, and observed meteorological forcing (Qian et al., 2006). We also evaluated the predicted methane fluxes at wetland and rice paddy sites against site-level model simulations. We then extended our parameterization to the global scale and estimated the terrestrial methane flux and its sensitivities to model parameterization choices.

While the CLM4 is a state-of-the-art land model for use in global climate simulations, in its current form the CLM4 does not have vertical representation of soil organic matter, accurate subgrid-scale hydrology and subgrid-scale heterotrophic respiration, realistic representation of inundated system vegetation, anaerobic decomposition, thermokarst dynamics, and aqueous chemistry. These shortcomings have also been emphasized in Riley et al. (2011). In this paper, we do not attempt to address these deficiencies except to use satellite-derived inundation data to reduce the dependence of the methane emissions on modeled hydrology. Other scientists are working to improve the hydrology in the model (e.g., Lawrence et al., 2011 and Swenson et al., 2012). We acknowledge that shortcomings in the CLM will impact methane emission predictions (and examine this in Appendix F); however, the incorporation of methane emissions into the current generation of Earth system models, despite their deficiencies, is a necessary first step towards understanding the response of methane emissions to changes in climate.

In this paper, Sect. 2 describes several new features of this model beyond those originally described in Riley et al. (2011). The datasets used to drive the model are described in Sect. 3. Model validation and comparisons with observations as well as sensitivity analysis are presented in Sect. 4. 
Discussion of the global methane flux is presented in Sect. 5, and conclusions are in Sect. 6.

\section{Model descriptions and modifications}

The methane biogeochemical model (CLM4Me) is integrated in the land component (CLM4) of the Community Earth System Model (CESM1). CLM4Me represents five processes relevant to $\mathrm{CH}_{4}$ emission prediction: methane production, methane oxidation, methane ebullition, methane transport through wetland plant aerenchyma, and methane diffusion through soil. In CLM4Me, production of $\mathrm{CH}_{4}$ below the water table $\left(P\left(\mathrm{~mol} \mathrm{C} \mathrm{m}^{-2} \mathrm{~s}^{-1}\right)\right)$ is related to the grid cell estimate of heterotrophic respiration from soil and litter $\left(R_{\mathrm{h}}\left(\mathrm{mol} \mathrm{C} \mathrm{m} \mathrm{m}^{-2} \mathrm{~s}^{-1}\right)\right)$, soil temperature $\left(Q_{10}^{\prime}\right), \mathrm{pH}\left(f_{\mathrm{pH}}\right)$, redox potential $\left(f_{\mathrm{pE}}\right)$, and a factor accounting for the portion of the grid cell that is seasonally inundated $(S)$ :

$$
P=R_{\mathrm{H}} f_{\mathrm{CH}_{4}} Q_{10}^{\prime} S f \mathrm{pH} f \mathrm{pE} .
$$

Here, $f_{\mathrm{CH}_{4}}$ is the ratio between $\mathrm{CO}_{2}$ and $\mathrm{CH}_{4}$ production, which is currently set to 0.2 for wetlands and rice paddies. We conduct the model simulations by using satellite inundation and a global distribution of $\mathrm{pH}$. In the CLM4Me simulations described in Riley et al. (2011), $f_{\mathrm{pH}}$ is set to 1 and $f_{\mathrm{pE}}$ varies in seasonally inundated systems by assuming that alternative electron acceptors are reduced with an e-folding time of 30 days after inundation; both of these parameters are varied for sensitivity analysis. The $\mathrm{pH}$ and redox potential functions and other modifications from CLM4Me are described in detail in the following subsections, and together are referred to as CLM4Me'.

\subsection{Soil pH effects on methanogenesis}

Soil $\mathrm{pH}$ has an important control on methane production with maximum rates at neutral $\mathrm{pH}$ conditions (Wang et al., 1993; Zhuang et al., 2004; Minami, 1989; Dunfield et al., 1993; Conrad and Schutz, 1988). We used the data from Dunfield et al. (1993) to develop a new soil $\mathrm{pH}$ function $\left(f_{\mathrm{pH}}\right)$ :

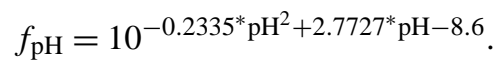

The maximum methane production occurs at $\mathrm{pH} \sim 6.2$ (Fig. 1). Compared with other functions used to specify the $\mathrm{pH}$ dependence of methane emissions (Zhuang et al., 2004; Cao et al., 1995), the advantage of this new $\mathrm{pH}$ function is that it allows for small but finite methane production at acidic $\mathrm{pH}$. Several studies have shown that methane can be produced in acidic conditions, e.g., at $\mathrm{pH}$ of 4.0 in northern bogs (Williams and Crawford, 1985; Valentine et al., 1994). Another difference between our function and that in Cao et al. (1995) is the optimal $\mathrm{pH}$ for methanogenesis, which is 7.5 in Cao et al. (1995) and 6.2 here.

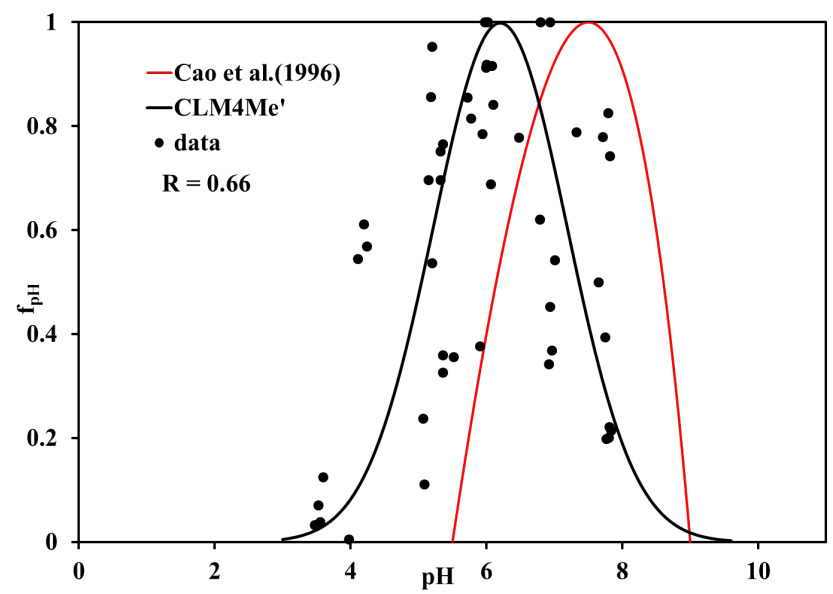

Fig. 1. $\mathrm{PH}$ function used in the model (Black line). The optimal $\mathrm{pH}$ for methanogenesis is 6.2 in our $\mathrm{pH}$ function. The red line shows $\mathrm{pH}$ function used in Cao et al. (1996) with optimal $\mathrm{pH}$ 7.5.

\subsection{Redox potential effects on methanogenesis}

Methane is produced in anoxic soils only when all oxidized species such as $\mathrm{NO}_{3}^{-}, \mathrm{Fe}(\mathrm{III})$, and $\mathrm{SO}_{4}^{2-}$ are consumed because these chemical species fuel microbial activities at the expense of methanogenesis (Lovley and Phillips, 1987). Theoretically, methane production occurs only when redox potentials $\left(E_{h}\right)$ in soil are below $-200 \mathrm{mV}$ (Wang et al., 1993; Neue et al., 1990). $E_{h}$ reflects the abundance of alternative electron acceptors (such as $\mathrm{O}_{2}, \mathrm{NO}_{3}^{-}, \mathrm{Fe}^{+3}, \mathrm{Mn}^{4+}, \mathrm{SO}_{4}^{2-}$ ) which can suppress methanogenesis through the reduction of $\mathrm{H}_{2}$ (Conrad, 2002) and supply more energy than available through methanogenesis (Zehnder and Stumm, 1988). Once these alternative electron acceptors have been depleted, $\mathrm{H}_{2}$ will increase to a level that methanogens can use to produce methane. The duration of suppression of the alternative electron acceptors on methanogenesis will depend on their concentrations in soils and availability of acetate and $\mathrm{H}_{2}$. The effect of redox potential has been incorporated into several previous methane models (e.g., Zhuang et al., 2004, Zhang et al., 2002, and Li et al., 2000). For instance, Zhuang et al. (2004) calculated $E_{h}$ based on the status of soil saturation assuming that $\mathrm{O}_{2}$ is the dominant alternative electron acceptor that suppresses methanogenesis. Li et al. (2000) developed a simple dynamic model to estimate soil redox potential based on soil oxygen pressure, which is calculated through soil oxygen diffusion and consumption. In submerged soil, reducible $\mathrm{Fe}$ (III) is one of the most abundant electron acceptors. Studies have suggested that methane production will not occur until a significant amount of Fe (III) has been reduced to Fe (II) (Cheng et al., 2007; Conrad, 2002). Based on laboratory experiments, Cheng et al. (2007) developed an empirical model to include soil chemical properties (such as available $\mathrm{N}$ and $\mathrm{Fe}$ (II)) in predicting methane emissions from Japanese rice paddy soils. They showed that methane 


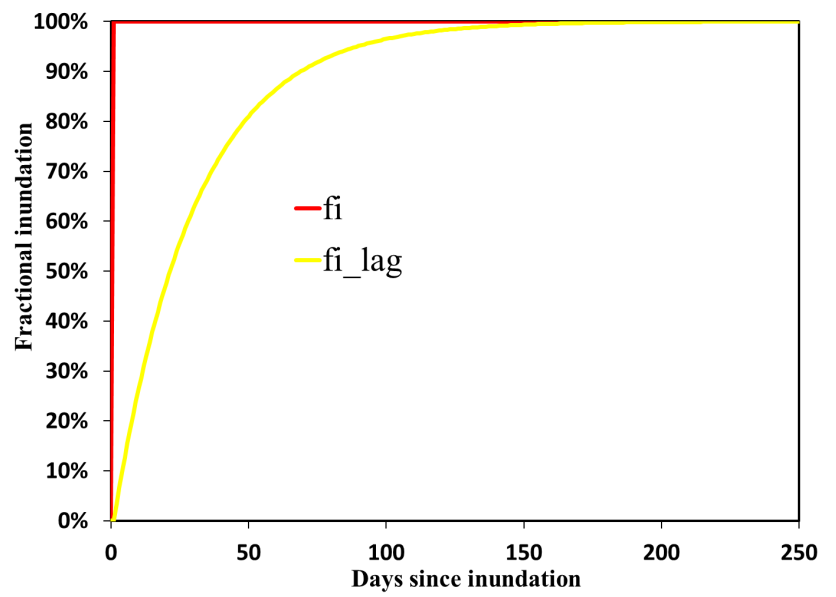

Fig. 2. An illustrative diagram of the impact of redox potential on inundated fraction. $\mathrm{fi}$ is representative of the inundated fraction that is predicted by the model. $f_{i_{\text {lag }}}$ is the inundated fraction that is actively producing methane.

production is significantly related to reducible $\mathrm{Fe}$ and decomposable $\mathrm{C}$ and found that methane production is delayed by 4-8 weeks for different types of soils due to the abundance of reducible Fe. Due to the lack of globally available datasets for reducible $\mathrm{Fe}$ and other species, we do not estimate the delay time on a spatially explicit basis.

Here we developed a simple parameterization of the effects of redox potential by assuming newly inundated wetlands will not produce methane initially because of the existing electron acceptors (such as $\mathrm{O}_{2}, \mathrm{SO}_{4}^{-2}, \mathrm{Fe}^{3+}$, etc) regenerated by $\mathrm{O}_{2}$ prior to the flooding. As other electron acceptors are consumed following the flooding, the inundated fraction that can produce methane increases. We assumed a time constant of 30 days (the average time for other electron acceptors to be consumed) for the resumption of methane production. Such delayed impacts have been demonstrated in other studies (Conrad, 2002; Cheng et al., 2007; Lovley and Phillips, 1987; van Bodegom and Stams, 1999). This redox function was first introduced in Riley et al. (2011). Here we provide more detailed information about this function. We incorporated the redox potential into CLM4Me in the inundated and non-inundated fractions separately.

We adjusted the fractional inundation in each grid cell to account for changing redox potential. Therefore, the redox potential factor $f_{\mathrm{pE}}$ in Eq. (1) is calculated as follows:

$f_{i_{\text {lag }}(t)}=f_{\text {redox }}(t)-f_{\text {redox }}(t)$

$f_{\text {redox }}(t)=f_{i}(t)-f_{i}(t-1)+f_{\text {redox }}(t-1) \cdot(1-\Delta t / \tau)$
$f_{\mathrm{pE}}=\frac{f_{i_{\mathrm{lag}}}(t)}{f_{i}(t)}$

where $f_{i}(t)$ is the fractional inundation, $f_{i_{\mathrm{lag}}(t)}$ is the adjusted fractional inundation that is producing methane, $f_{\text {redox }}(t)$ is the fraction of grid cell where alternative electron acceptors (such as $\mathrm{O}_{2}, \mathrm{NO}_{3}^{-}, \mathrm{Fe}^{+3}$ ) are consumed (i.e., methane production is completely inhibited), $\Delta \mathrm{t}$ is the time step, and $\tau$ is the time constant currently set to 30 days. Thus, $f_{\text {redox }}(t)$ is equal to the newly inundated fraction of land plus a relaxation of the previously inundated fraction to zero. These are new equations that we derived based on current understanding of the impact of redox potential on methane production. Figure 2 shows the adjusted fractional inundation $\left(f_{i_{\text {lag }}}\right)$ against original fractional inundation.

In the non-inundated fraction, we estimated the delay in methane production as the water table depth increases by estimating an effective depth below which $\mathrm{CH}_{4}$ production can $\operatorname{occur}\left(Z_{i_{\mathrm{lag}}}\right)$ :

$Z_{i_{\text {lag }}}(t)=Z_{i}(t)-Z_{\text {redox }}(t)$

$Z_{\text {redox }}(t)=Z_{i}(t)-Z_{i}(t-1)+Z_{\text {redox }}(t-1) \cdot 1-\Delta t / \tau$

where $Z_{\text {redox }}$ is the depth of saturated water layer where alternative electron acceptors are consumed and $Z_{i}$ is the actual water table depth. We then used $Z_{i_{\text {lag }}}$ for methane production in the unsaturated portion in each grid cell. This approach is a simplification of the true dynamics of redox species concentrations and their impact on $\mathrm{CH}_{4}$ production, which include vertical transport and multiple transformation processes. Future work in global-scale models should address this simplification.

\subsection{Methane oxidation in the rhizosphere}

In wetlands and rice paddies, plants develop aerenchyma to facilitate oxygen transport for root respiration and to support microbial activity in the soil-root rhizosphere. However, aerenchyma can also serve as conduits for methane to escape to the atmosphere (Colmer, 2003). Studies suggest that aerenchyma can be a dominant pathway for plantmediated transfer of methane from soil to the atmosphere with up to $90 \%$ of the total methane emissions via transport in the aerenchyma from the rhizosphere (Cicerone and Shetter, 1981; Nouchi et al., 1990). While the methane is escaping through aerenchyma, some of it can be oxidized by the available oxygen. Therefore, rhizospheric methane oxidation can have a large control on global methane budgets. In CLM4Me, competition of root respiration and methanotrophy for the available oxygen determines the fraction of methane that is oxidized in the rhizosphere before being released into the atmosphere through aerenchyma. The balance between transport and oxidation depends on the availability of oxygen in the rhizosphere (Riley et al., 2011). The 
amount of $\mathrm{O}_{2}$ that can be brought to the root depends on several factors including temperature, light intensity, water table change, and plant physiology (Whiting and Chanton, 1996; van der Nat and Middelburg, 1998). For instance, van der Nat and Middelburg (1998) investigated seasonal variation in rhizospheric methane oxidation of two common wetland plants (reed and bulrush) in a well-controlled environment and found that rhizospheric methane oxidation peaked during the early plant growth cycle and decreased after plants matured and root respiration decreased. We selected two sites where field-measured rhizospheric oxidation fractions were measured for comparison with model predictions. A sensitivity analysis was also conducted to characterize the impact of uncertainty in maximum oxidation fraction $\left(R_{o, \max }\right)$ on rhizospheric oxidation.

\subsection{Existence of aerenchyma in mostly inundated wetlands}

In this study, we assumed that plant aerenchyma develops only in plants restricted to continuously inundated land. Although, aerenchyma represents one adaptation to inundation, there are other differences between wetland plants and other plant types in their ability to deal with inundation. Studies suggest that some plants in dry land do not form aerenchyma (Voesenek et al., 1999), given the metabolic cost to construct and maintain tissue. Rather, they adjust physiologically to seasonal flooding (Colmer, 2003; Voesenek and Blom, 1989). For instance, some cultivars of Brassica napus tend to develop new roots near the water surface in response to waterlogging (Voesenek et al., 1999; Daugherty et al., 1994). Because CLM4 does not have a wetland plant functional type (pft), the methodology adapted here is designed to improve our ability to simulate soil methane dynamics without adding a new wetland pft (which in the long term is a better solution). Here we define the maximum fraction of inundated land $\left(f_{m}\right)$ where plants develop aerenchyma as the long-term (1993-2004) mean NPP flux weighted fractional inundation $\left(f_{i}\right)$ at each grid cell:

$$
f_{m}=\frac{\sum_{i} f_{i} \cdot \mathrm{NPP}_{i}}{\sum_{i} \mathrm{NPP}_{i}}
$$

where $\mathrm{NPP}_{i}$ is the simulated average NPP at month $i$ in the CLM4CN. We weight the inundated fraction with NPP so as to only take into account the seasonal variation of growing season and inundation (e.g to determine if it is inundated in the growing season, when methane is released). To implement this feature into the model, at each grid cell we decrease plant aerenchyma area $(T)$ evenly across all inundated area if current inundated fraction $\left(f_{i}\right)$ is greater than $f_{m}$ as follows:

$T^{*}=T \cdot f_{\text {aere }}$

$f_{\text {aere }}=\min \left(1, f_{m} / f_{i}\right)$
This new feature sets the limit of plants with aerenchyma to the mean inundated area and increases maximum aerenchyma area in plants when mean inundated fraction increases, which agrees with other studies that show the increase of aerenchyma in wetland plants in response to flooding (Fabbri et al., 2005; Kolb and Joly, 2009). However, this model feature may underestimate aerenchyma area in unflooded plants as formation of aerenchyma in some plants is not controlled by flooding conditions (Fabbri et al., 2005). This relationship only applies to natural wetlands since rice paddies are assumed to always be inundated in this study.

\subsection{NPP-adjusted methane flux}

Uncertainties in simulated methane fluxes could possibly come from errors associated with simulated NPP (Riley et al., 2011). By comparing with observation-based estimate NPP, we adjusted simulated methane fluxes and evaluated how improved NPP could increase the predictability of methane emissions. We applied the following equation to predict simulated methane flux $\left(\mathrm{F}_{\mathrm{CH}_{4}}\right)$ :

$F_{\mathrm{CH}_{4}}=F_{\mathrm{CH}_{4}} \frac{\mathrm{NPP}_{\text {MODIS }}}{\mathrm{NPP}_{\text {model }}}$

where $F_{\mathrm{CH}_{4}}$ is the NPP-adjusted daily methane flux (mg $\mathrm{CH}_{4} \mathrm{~m}^{-2} \mathrm{~d}^{-1}$ ), NPP MODIS is the annual mean NPP derived from MODIS, and NPP model is the annual mean NPP simulated in the CLM4CN. We applied this factor only to test the impact of substrate production uncertainty on methane emissions and not to modify our global emission estimates. We applied this factor only to the sites tested in this study.

\subsection{Modifications for rice paddies}

In the model, the major differences between rice paddy and natural wetlands are that (1) rice paddies are treated as continuously inundated areas while natural wetlands are seasonally inundated, and (2) we applied the crop pft to represent rice, as the crop pft is the closest to rice in CLM4. For wetland simulations, we used the spin-up described in Riley et al. (2011) to initialize model simulations. For rice paddy simulations, we used the year 2000 atmospheric forcing (Qian et al., 2006) with unlimited nitrogen to spin-up the CLM4 model offline simulation. We also assumed only one crop pft in each grid cell, so that the soil column would only contain rice; normally in CLM4, PFTs share a single soil column. This new spin-up is used to initialize the rice paddy simulation. In addition, only methane emissions from the inundated fraction in each grid cell are used to calculate the grid cell mean emissions in the rice paddy simulations. The methane emissions from non-inundated fraction were excluded when calculating grid cell mean emissions in rice paddy module. 


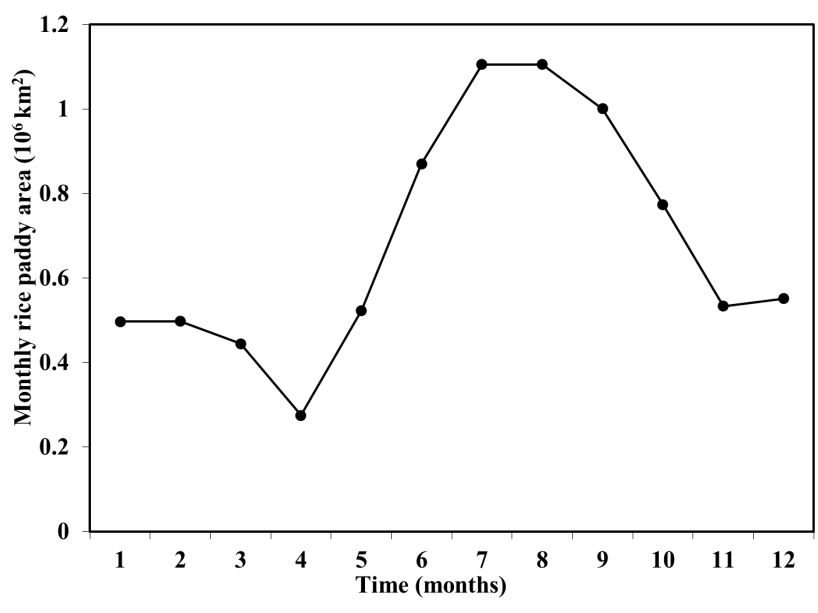

Fig. 3. Seasonal variation of global rice paddy areas in year 2000 (Portmann et al. 2010). The rice paddy area peaks in July and August.

\subsection{Model setup for point and global simulations}

We compared simulated methane emissions to site level observations by running the methane emission model in point simulations as well as at the global level. For point simulations, we used the atmospheric forcing data (Qian et al. 2006) from the overlapping grid cell. Then we spun-up the model for each site by running CLM4CN as a single-point model for more than $1000 \mathrm{yr}$ until the soil carbon stabilized. For these single-point simulations, we did not consider the grid-cell averaged flux for the evaluation of our model. Instead, we calculated the methane emission fluxes from either the unsaturated or saturated portion of the grid cell depending on the local water table measurements at the site location. When the measured water table was above the surface, we assumed the measured flux at the site was represented by the simulated flux in the saturated portion of the grid cell; when the measured water table was below the surface, we assumed the measured flux was represented by the simulated flux in the unsaturated portion of the grid cell, where the simulated water table position is taken to be the monthly water table position at the measurement location. The imposed water table level is used for the methane-related calculation of anaerobicity, production, oxidation, etc., but does not include the expected impact of water table on soil temperature. For global wetland simulations, we used the spin-up described in Riley et al. (2011) to initialize an offline 1993-2004 run with observed meteorological forcing and evaluated the methane flux on a grid-cell averaged basis. In the global simulations the fraction of inundation was taken from the satellite measurements. For rice paddy simulations, we used the spin-up described in Sect. 2.6 to initialize an offline run for year 2000.

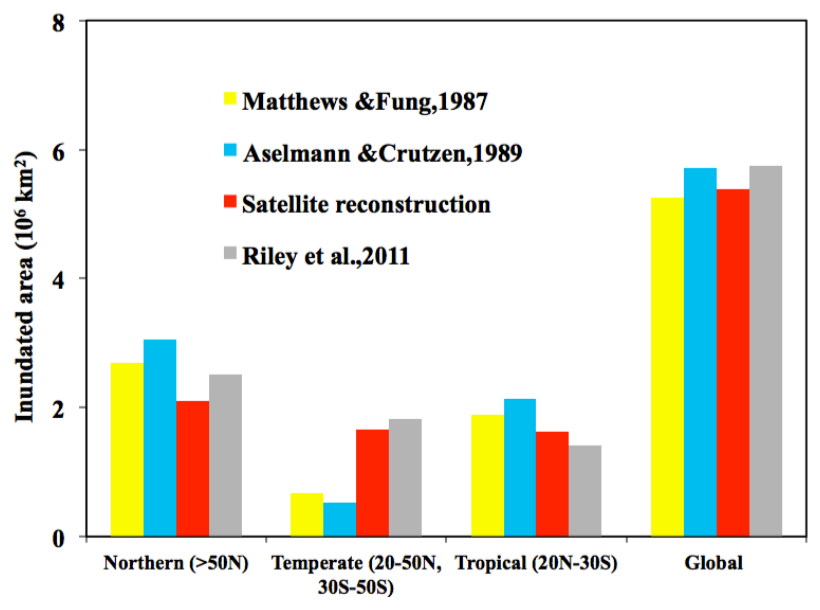

Fig. 4. Comparison of inundated areas used in different methane models with error bars indicating the range of annual mean inundated areas. For satellite reconstruction and Riley et al. (2011), we used the maximum monthly inundated area during the period 19932000. Please note that rice paddy area was removed from the satellite reconstruction.

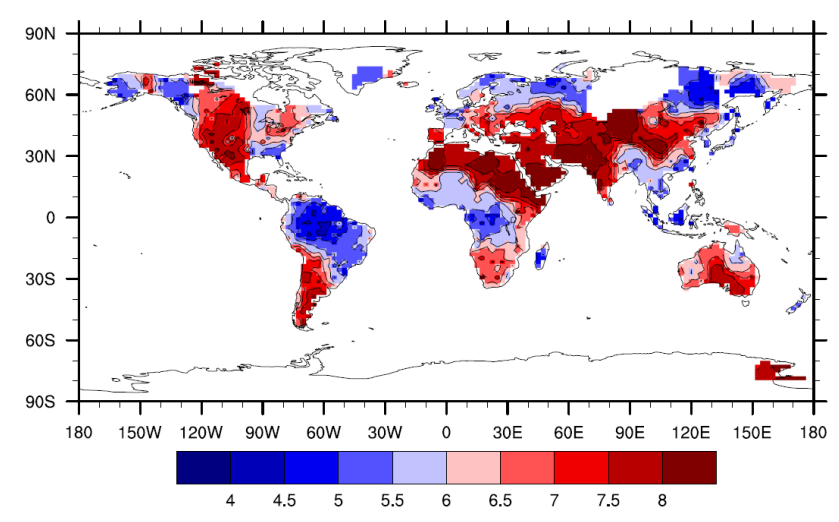

Fig. 5. The global distribution of soil pH. Data Sources: IGBPDIS (see Tempel et al. (1966) and Pleijsier (1986)).

\subsection{Calculation of rhizospheric methane oxidation fraction}

In order to calculate the fraction of methane oxidized in the rhizosphere, we conducted two single-point simulations for each of the two sites with data on plant aerenchyma. One simulation assumed that all methane transported through aerenchyma from the rhizosphere was released into the atmosphere without loss (hereafter referred to as "NoLoss"), and the other considered methane oxidation loss in the rhizosphere before being emitted into the atmosphere (hereafter referred to as "WithLoss"). The rhizospheric methane oxidation fraction was computed as the ratio of calculated methane flux differences between NoLoss and WithLoss to methane flux that was transported through aerenchyma in NoLoss. This method for calculating rhizospheric oxidation 


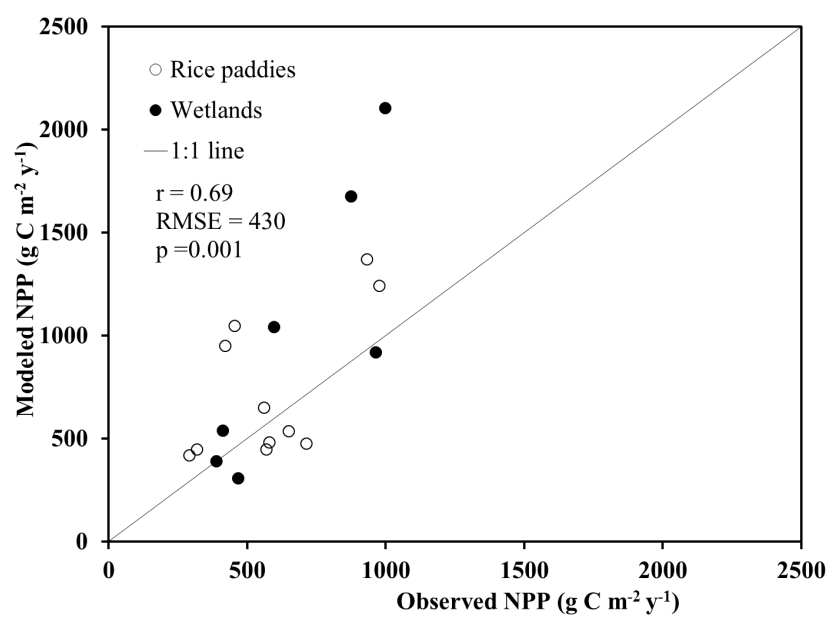

Fig. 6. Scatter plot of modeled annual NPP vs. observed annual mean NPP at the rice paddy and wetland sites. The observed annual mean NPP was obtained from MODIS (Zhao et al., 2005). $r$ is correlation coefficient; RMSE indicates root-mean-square error, and $p$ is probability level. (Alberta, Canada; Florida, USA)

is comparable to the way it was calculated in the field experiment. In our model, we assumed that vegetation communities at these two sites include significant amount of plants with aerenchyma.

\subsection{Calculation of aerenchyma area}

We also modified Eq. (5) in Riley et al. (2011) to use fine root $\mathrm{C}$ instead of leaf area index in calculating aerenchyma area, because fine root $\mathrm{C}$ calculated in CLM4-CN accounts for pft-specific and seasonal variations. This term better represents mass of tiller used in Wania et al. (2010) to calculate aerenchyma area. The equation is as follows:

$T=\frac{F_{\text {rootc }}}{0.22} \pi R^{2}$

where $F_{\text {rootc }}$ is pft-specific fine root carbon $\left(\mathrm{gC} \mathrm{m}^{-2}\right), R$ is the aerenchyma radius $\left(2.9 \times 10^{-3} \mathrm{~m}\right)$, and the 0.22 factor represents the amount of $\mathrm{C}$ per tiller. We will conduct a sensitivity analysis to test the impact of this change on global methane budget relative to that calculated using leaf area index.

\section{Datasets}

We used the datasets described below to force the methane emission model to the extent possible with observed data.

\subsection{Global distributions of wetlands and rice cultivation fields}

In CLM4 hydrology, the saturated fraction in a grid cell is calculated as function of water table depth and a spatially variable parameter. Comparison of CLM4 estimated saturated fraction with satellite inundation data suggests large differences in terms of magnitude, temporal and spatial patterns (Riley et al., 2011). To improve on this estimate, and to allow future projections, in CLM4Me we fit a simple diagnostic relationship between predicted water table depth and runoff to the satellite-derived inundation dataset of Prigent et al. (2007) at each grid cell around the world. In the current work, in order to remove the potential errors associated with these approaches to estimating inundated fraction and to focus on other important processes that control methane emissions, we constrained the inundated fraction by using satellite-derived data. (Appendix F includes a sensitivity study with inundated fraction predicted by model hydrology). We used satellite inundation data (1993-2004) provided by Prigent et al. (2007) and Papa et al. (2010) to represent the extent of natural wetlands and to include seasonal and interannual variability in our global simulations. The water table level in the non-inundated fraction is calculated from the satellite inundated fraction at each grid cell (see Appendix D). Soil moisture in the unsaturated zone and soil temperatures were calculated from CLM4 hydrology. As discussed in Prigent et al. (2007), the satellite inundation does not discriminate among inundated wetlands and irrigated agriculture; therefore, we removed the irrigated agriculture from the satellite inundation by assuming rice cultivation areas were inundated agricultural land. Monthly mean distributions of rice cultivation areas compiled by Portmann et al. (2010) were used to define rice location and area. Irrigated, rain-fed, and deepwater rice (Kende et al., 1998) areas are included in the rice cultivation areas. Due to the lack of information on water management, draining, and re-flooding during the rice-growing season at the global scale, we assumed that rice fields were continuously flooded from the beginning of rice planting to the end of rice harvest. Overall, global coverage of rice paddies totals $1.67 \times 10^{6} \mathrm{~km}^{2}$, which is slightly larger than the areas estimated by Matthews and Fung (1991) and Asemann and Crutzen (1989), which are $1.47 \times 10^{6}$ and $1.3 \times 10^{6} \mathrm{~km}^{2}$, respectively. Rice growth areas peaked in July and August in this dataset (Fig. 3). Comparison of satellite-derived inundated areas with wetland extents compiled from other sources shows large regional deficiencies (Fig. 4). On average, maximum satellite-derived inundated areas in northern latitudes are similar to wetland extents compiled by Matthews and Fung (1987) (hereafter referred to as "MF") and Aselmann and Crutzen (1989) (hereafter referred to as "AC"), respectively. There are some regional differences in wetland extents among these datasets. Maximum satellite inundated areas are $\sim 140 \%$ and $\sim 220 \%$ larger than $\mathrm{MF}$ and $\mathrm{AC}$ wetland extents in temperate regions and are $\sim 14 \%$ and $\sim 24 \%$ smaller than MF and AC wetland extents in tropical regions, respectively. Despite this deficiency, the satellite-derived dataset provides a powerful tool to constrain methane emissions as it provides seasonal variations in inundated areas that have large impacts on the 

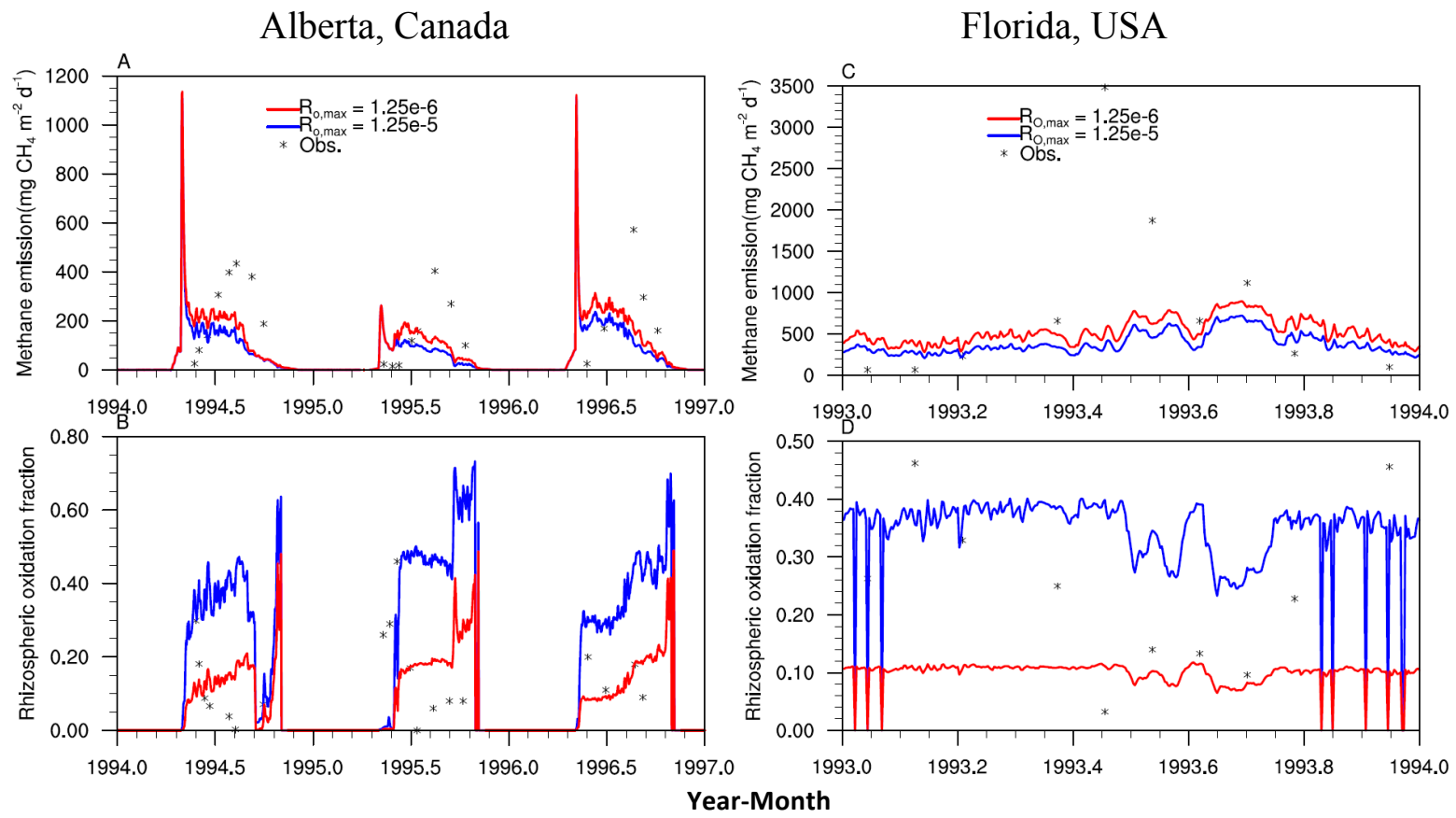

Fig. 7. Comparisons between model simulations and observation at Alberta (Canada) and Florida (USA) sites. For each site, the top figure shows comparison of methane emissions with different $R_{O, \max }$ values; the bottom figure shows the comparison of estimated rhizospheric oxidation fraction with different $R_{O}$, max with observations.

seasonal variation in methane emissions (and will be discussed below). The extent of satellite inundated area used in this study is different from that in Riley et al. (2011), who developed a simple best-fit relationship between CLM4 predicted water table depth and runoff and the satellitederived inundation estimates of Prigent et al. (2007). Riley et al. (2011) also added the constant IGBP inland water body to the satellite data in order to address the underestimation of inundated area in high latitudes. Averaged over the high latitudes, the mean inundated area used in Riley et al. (2011) is approximately $20 \%$ larger than satellite inundated fraction used in this study. As demonstrated below, the assumption of wetland extent can result in large differences in simulated global methane fluxes.

\subsection{Global soil $\mathrm{pH}$ datasets}

Global soil $\mathrm{pH}$ datasets for this study are from the global soil dataset of IGBP-DIS distributed by the International Soil Reference and Information Centre (Tempel et al., 1966) (http://www.isric.org) (Fig. 5). The original sources of these datasets are from the combination of international soil reference and information center's (ISRIC) soil information system (SIS) and CD-ROM of the Natural Resources Conservation Service (USDA-NRCS). The two datasets can be merged without issues of compatibility (Pleijsier, 1986). Note that this $\mathrm{pH}$ dataset does not necessarily represent wetland conditions, although soil $\mathrm{pH}$ is thought to be an im- portant control on wetland $\mathrm{pH}$ (Magdoff and Bartlett, 1985). However, this is the only available global soil $\mathrm{pH}$ dataset. A site-level comparison between wetland $\mathrm{pH}$ at each measurement site and IGBP soil $\mathrm{pH}$ at the closest location is shown in Appendix A (Fig. A1). The correlation between the two datasets is 0.69 , with a root-mean-square error of 1.07 .

\subsection{Observed meteorological forcing}

The observed meteorological forcing dataset that is provided with CLM4 extends from 1948 to 2004 at 3-hourly temporal and T62 $\left(\sim 1.875^{\circ}\right)$ spatial resolution. The dataset is a combination of observed monthly precipitation and temperatures with model-simulated intra-monthly variations from NCEPNCAR 6-hourly reanalysis (Qian et al., 2006).

\subsection{Rice paddies and wetland sites}

A total of 11 rice paddy fields (Table 1) and 7 natural wetland sites (Table 2) were selected to test our model simulations. The rice paddy fields include sites in Italy, Chengdu (China), Nanjing (China), Japan, California (USA), Texas (USA), New Delhi (India), Cuttack (India), Beijing (China), Central Java (Indonesia), and Lampung (Indonesia). The common feature of the selected rice growing seasons at these sites was that there was no drainage until harvest. At each location, the flooding and drainage dates were provided in their corresponding references (Table 1). The $\mathrm{pH}$ values were 
Table 1. Site descriptions for rice paddy fields.

\begin{tabular}{|c|c|c|c|c|c|c|c|c|c|c|}
\hline Site Name & Year & Location & $\mathrm{pH}$ & $\begin{array}{l}\text { Date of } \\
\text { field flooded }\end{array}$ & $\begin{array}{l}\text { Date of } \\
\text { final drainage }\end{array}$ & $\begin{array}{l}\text { Nitrogen } \\
\text { added }\end{array}$ & $\begin{array}{l}\text { Rice type } \\
\text { (cultivar) }\end{array}$ & $\begin{array}{l}\text { Measurement } \\
\text { techniques }\end{array}$ & $\begin{array}{l}\text { Soil } \\
\text { type }\end{array}$ & References \\
\hline $\begin{array}{l}\text { Texas, } \\
\text { USA }\end{array}$ & 1994 & $\begin{array}{l}29.95 \mathrm{~N} \\
265.5 \mathrm{E}\end{array}$ & N/A & 17-May & 11-Aug & Yes & Lemont & Chamber & Bernard-Morey & $\begin{array}{l}\text { Sigren et al. } \\
\text { (1997) }\end{array}$ \\
\hline Italy & 1991 & $\begin{array}{l}45.3 \mathrm{~N} \\
8.42 \mathrm{E}\end{array}$ & 6 & 7-May & 30-Aug & Yes & Roma/Lido & $\begin{array}{l}\text { Static (Closed) } \\
\text { Chamber }\end{array}$ & Sandy loam & $\begin{array}{l}\text { Butterbach- } \\
\text { Bahl et al. } \\
\text { (1997) }\end{array}$ \\
\hline $\begin{array}{l}\text { Chengdu, } \\
\text { China }\end{array}$ & 2003 & $\begin{array}{l}31.27 \mathrm{~N} \\
105.45 \mathrm{E}\end{array}$ & 8.1 & 9-May & 7-Sep & Yes & $\begin{array}{l}\text { hybrid II- } \\
\text { You } 162\end{array}$ & Chamber & Purplish & $\begin{array}{l}\text { Jiang et al. } \\
(2006)\end{array}$ \\
\hline $\begin{array}{l}\text { Nanjing, } \\
\text { China }\end{array}$ & 1999 & $\begin{array}{l}32.8 \mathrm{~N} \\
118.75 \mathrm{E}\end{array}$ & N/A & 18-Jun & 13-Oct & Yes & \# 9561 & Chamber & Hydromorphic & $\begin{array}{l}\text { Huang et al. } \\
\text { (2001) }\end{array}$ \\
\hline $\begin{array}{l}\text { California, } \\
\text { USA }\end{array}$ & 1982 & $\begin{array}{l}40.2 \mathrm{~N} \\
237.98 \mathrm{E}\end{array}$ & N/A & 11-May & 2-Oct & Yes & M101 & $\begin{array}{l}\text { Static } \\
\text { chamber }\end{array}$ & Capay silty clay & $\begin{array}{l}\text { Cicerone et al } \\
\text { (1992), } \\
\text { Cierone et al. } \\
\text { (1983) }\end{array}$ \\
\hline & 1983 & & & 21-May & 1-Oct & Yes & & & & \\
\hline \multirow[t]{2}{*}{ Japan } & 1991 & $\begin{array}{l}36.02 \mathrm{~N} \\
140.22 \mathrm{E}\end{array}$ & $6.6-6.9$ & 7-May & 12-Aug & Yes & Koshihikari & $\begin{array}{l}\text { Automatic } \\
\text { chamber }\end{array}$ & $\begin{array}{l}\text { Gley soil } \\
\text { (Sandy clay loam) }\end{array}$ & $\begin{array}{l}\text { Yagi et al. } \\
\text { (1996) }\end{array}$ \\
\hline & 1993 & & $6.6-6.9$ & 7-May & 2-Sep & Yes & Koshihikari & & & \\
\hline \multirow[t]{2}{*}{$\begin{array}{l}\text { New Delhi, } \\
\text { India }\end{array}$} & 1995 & $\begin{array}{l}20.08 \mathrm{~N} \\
77.12 \mathrm{E}\end{array}$ & 8.2 & 1-Jul & 1-Nov & Yes & IR72 & $\begin{array}{l}\text { Closed } \\
\text { chamber, } \\
\text { manual }\end{array}$ & $\begin{array}{l}\text { Ustochrept } \\
\text { (sandy loam) }\end{array}$ & $\begin{array}{l}\text { Jain et al. } \\
(2000)\end{array}$ \\
\hline & 1996 & & & & & & & & & \\
\hline $\begin{array}{l}\text { Cuttack, } \\
\text { India }\end{array}$ & 1996 & $\begin{array}{l}20.42 \mathrm{~N}, \\
85.92 \mathrm{E}\end{array}$ & 6.19 & 19-Jul & $30-$-Oct & Yes & CR 749-20-2 & $\begin{array}{l}\text { Automatic } \\
\text { chamber }\end{array}$ & $\begin{array}{l}\text { Haplaquept } \\
\text { (Alluvial) }\end{array}$ & $\begin{array}{l}\text { Adhya et al. } \\
(2000)\end{array}$ \\
\hline $\begin{array}{l}\text { Beijing, } \\
\text { China }\end{array}$ & 1995 & $\begin{array}{l}40.55 \mathrm{~N} \\
116.78 \mathrm{E}\end{array}$ & 7.99 & 4-Jun & 17-Oct & Yes & Zhongguo & $\begin{array}{l}\text { Automatic } \\
\text { chamber }\end{array}$ & silty clay loam & $\begin{array}{l}\text { Wang et al. } \\
(2000)\end{array}$ \\
\hline $\begin{array}{l}\text { Central } \\
\text { Java, } \\
\text { Indonesia }\end{array}$ & 2001-2002 & $\begin{array}{l}6.63 \mathrm{~S} \\
110 \mathrm{E}\end{array}$ & 5.1 & 1-Nov & $28-\mathrm{Feb}$ & Yes & $\begin{array}{l}\text { Memberamo, } \\
\text { Cisadane, } \\
\text { IR64, Way } \\
\text { Apoburu }\end{array}$ & $\begin{array}{l}\text { Automatic } \\
\text { closed } \\
\text { chamber }\end{array}$ & $\begin{array}{l}\text { Aeric Tropaquept } \\
\text { (Silty loam) }\end{array}$ & $\begin{array}{l}\text { Setyanto et al. } \\
(2004) \\
\text { (Indonesia } \\
\text { J. Agri. Sci.) }\end{array}$ \\
\hline $\begin{array}{l}\text { Lampung, } \\
\text { Indonesia }\end{array}$ & 1993 & $\begin{array}{l}\text { 4.52S, } \\
105.3 \mathrm{E}\end{array}$ & 5 & 21-Nov & 4-Mar & Yes & $\begin{array}{l}\text { Oryza sativa } \\
\text { var. IR-64 }\end{array}$ & Chamber & $\begin{array}{l}\text { Typic Paleudult } \\
\text { (Sandy clay) }\end{array}$ & $\begin{array}{l}\text { Nugroho et al. } \\
\text { (1994) } \\
\text { (SSPN) }\end{array}$ \\
\hline
\end{tabular}

set to 6.2 (optimal pH) when not available. The soil types on paddies are mainly loam and clay. These sites were chosen to cover major rice growing regions with a focus on Asia.

The wetland comparison includes sites in Panama, Indonesia, Florida, Minnesota, Michigan, Alberta (Canada), and Finland, covering the tropics, mid-latitudes, and high latitudes. Measured water table positions were integrated into the model to simulate methane emissions at these natural wetland sites (except the Panama site which used modeled water table positions). We assumed that soil was inundated below the water table. These wetland sites usually have peat soils with varying depths underlain by mineral soil. Methane is produced in the wetlands from litter and dead vegetation remnants in anoxic conditions. For these site-level comparisons, we used NCEP-NCAR reanalysis atmospheric forcing (including precipitation, temperature, wind speeds, and solar radiation) (Qian et al., 2006), $\mathrm{pH}$ from the site level measurement, and redox potential effects on production.

\section{Results: model testing and sensitivity analysis}

Here we discuss the comparisons of the model against sitelevel observations. The selected wetland sites (Table 2) have varying water table positions obtained from measurements (except Panama where simulated water table was used). At the northern latitude sites, water table level will not control methane emissions during winter when the surface is frozen.

\subsection{Net primary production (NPP)}

We compared the long-term annual mean NPP derived from the MODerate Resolution Imaging Spectroradiometer (MODIS) and obtained from the Numerical Terradynamic Simulation Group (NTSG) (http://www.ntsg.umt.edu) (Zhao et al., 2005) with that calculated by CLM4CN. We note that the MODIS-derived NPP is a combination of observed satellite reflectances and an ecosystem model (which does not explicitly represent wetland plants), and as such is not an ideal independent observation for comparison. Measured and simulated NPP are highly correlated, although the simulated NPP tends to overestimate observations, particularly at higher levels of NPP (Fig. 6), consistent with previous comparisons (Randerson et al., 2009). 
Table 2. Descriptions of wetland sites used in this study.

\begin{tabular}{|c|c|c|c|c|c|c|c|c|}
\hline Site Name & Location & Wetland type & $\begin{array}{l}\text { Dominant } \\
\text { vegetation }\end{array}$ & $\begin{array}{l}\text { Mean Precipitation and } \\
\text { temperature }\end{array}$ & $\begin{array}{l}\text { Soil and climate } \\
\text { characteristics }\end{array}$ & $\begin{array}{l}\text { Measurement } \\
\text { technique }\end{array}$ & Forcing data* & References \\
\hline $\begin{array}{l}\text { Central } \\
\text { Kalimantan, } \\
\text { Indonesia }\end{array}$ & $\begin{array}{l}2.33 \mathrm{~S} \\
113.92 \mathrm{E}\end{array}$ & $\begin{array}{l}\text { Ombrotrophic } \\
\text { peatland }\end{array}$ & $\begin{array}{l}\text { Evergreen broad- } \\
\text { leaved } \\
\text { trees }\end{array}$ & $\begin{array}{l}\text { Mean precipitation is } \\
2331 \mathrm{~mm} \text { and mean } T \\
\text { is } 26.3^{\circ} \mathrm{C} \text { between } \\
2002 \\
\text { and } 2005\end{array}$ & $\begin{array}{l}\text { wet season from } \\
\text { October to May and } \\
\text { dry season from June to } \\
\text { September, soil pH is } \\
4.0\end{array}$ & $\begin{array}{l}\text { Dark Static } \\
\text { chamber }\end{array}$ & $\begin{array}{l}\text { measured water table } \\
\text { positions }\end{array}$ & $\begin{array}{l}\text { Jauhiainen et al. } \\
\text { (2005) }\end{array}$ \\
\hline Panama & $\begin{array}{l}9 \mathrm{~N} \\
80 \mathrm{~W}\end{array}$ & Swamp & Palms & $\begin{array}{l}\text { Mean precipitation is } \\
1600 \mathrm{~mm} \text { in Panama } \\
\text { city and mean } \\
\text { temperature is } 27^{\circ} \mathrm{C}\end{array}$ & $\begin{array}{l}\text { Four-month dry season } \\
\text { between February and } \\
\text { May. Soil pH is } 6.2\end{array}$ & Static chamber & $\begin{array}{l}\text { modeled water table } \\
\text { positions from Walter } \\
\text { and Heimann (2000) }\end{array}$ & $\begin{array}{l}\text { Keller (1990); } \\
\text { Walter and Heimann } \\
\text { (2000) }\end{array}$ \\
\hline $\begin{array}{l}\text { Florida, } \\
\text { USA }\end{array}$ & $\begin{array}{l}30.07 \mathrm{~N} \\
275.8 \mathrm{E}\end{array}$ & Swamp & $\begin{array}{l}\text { Sagittaria } \\
\text { lancifolia }\end{array}$ & $\begin{array}{l}\text { Annual precipitation } \\
\text { is about } 1400 \mathrm{~mm}\end{array}$ & soil $\mathrm{pH}$ is 6.2 & Open chamber & fully saturated areas & $\begin{array}{l}\text { Lombardi et al. } \\
\text { (1997) }\end{array}$ \\
\hline $\begin{array}{l}\text { Salmisuo, } \\
\text { Eastern } \\
\text { Finland }\end{array}$ & $\begin{array}{l}62.75 \mathrm{~N}, \\
30.93 \mathrm{E}\end{array}$ & $\begin{array}{l}\text { Minerogenic, } \\
\text { oligotrophic } \\
\text { pine fen }\end{array}$ & $\begin{array}{l}\text { Sphagnum } \\
\text { papillosum }\end{array}$ & $\begin{array}{l}\text { Mean temperature is } \\
\text { about } 10^{\circ} \mathrm{C}\end{array}$ & $\begin{array}{l}\text { wet conditions from } \\
\text { July to September }\end{array}$ & Static chamber & $\begin{array}{l}\text { measured water table } \\
\text { positions }\end{array}$ & $\begin{array}{l}\text { Saarnio et al. } \\
\text { (1997) }\end{array}$ \\
\hline $\begin{array}{l}\text { Michigan, } \\
\text { USA }\end{array}$ & $\begin{array}{l}42.45 \mathrm{~N}, \\
84 \mathrm{~W}\end{array}$ & $\begin{array}{l}\text { Ombrotrophic } \\
\text { peatland }\end{array}$ & $\begin{array}{l}\text { Sphagnum, } \\
\text { Scheuchzeria } \\
\text { palustris, Vac- } \\
\text { cinium oxycoccos }\end{array}$ & $\begin{array}{l}\text { Mean precipitation for } \\
1948-80 \text { is } 761 \mathrm{~mm}\end{array}$ & soil pH 4.2 & Static chamber & $\begin{array}{l}\text { measured water table } \\
\text { positions }\end{array}$ & $\begin{array}{l}\text { Shannon and White } \\
\text { (1994) }\end{array}$ \\
\hline $\begin{array}{l}\text { Minnesota, } \\
\text { USA }\end{array}$ & $\begin{array}{l}47.53 \mathrm{~N} \\
266.53 \mathrm{E}\end{array}$ & $\begin{array}{l}\text { Poorly- } \\
\text { minerotrophic } \\
\text { to } \\
\text { ombrotrophic } \\
\text { peatland }\end{array}$ & $\begin{array}{l}\text { Sphagnum, } \\
\text { Chamaedaphne } \\
\text { calyculata, } \\
\text { Scheuchzeria } \\
\text { palustris }\end{array}$ & $\begin{array}{l}\text { Average precipitation } \\
\text { is } 553 \mathrm{~mm} \text { and mean } \\
\text { temperature is about } \\
13.6^{\circ} \mathrm{C} \text { for the } \\
\text { May-October period }\end{array}$ & soil $\mathrm{pH}$ is 4.6 & $\begin{array}{l}\text { Eddy } \\
\text { correlation } \\
\text { technique }\end{array}$ & $\begin{array}{l}\text { measured water table } \\
\text { positions }\end{array}$ & $\begin{array}{l}\text { Shurpali and Verma } \\
\text { (1998) }\end{array}$ \\
\hline $\begin{array}{l}\text { Alberta, } \\
\text { Canada }\end{array}$ & $\begin{array}{l}54.6 \mathrm{~N} \\
246.6 \mathrm{E}\end{array}$ & $\begin{array}{l}\text { Nutrient } \\
\text { rich fen }\end{array}$ & $\begin{array}{l}\text { Carex aquatilis and } \\
\text { Carex rostrata }\end{array}$ & N/A & $\begin{array}{l}\text { The freeze-thaw cycle } \\
\text { spans from May to } \\
\text { October, } \mathrm{pH}=7\end{array}$ & Open chamber & fully saturated areas & $\begin{array}{l}\text { Popp et al. } \\
(2000)\end{array}$ \\
\hline
\end{tabular}

* all sites use NCEP atmospheric forcing.

Table 3. Model performance statistics for the Base and NopH simulations at selected wetland sites.

\begin{tabular}{lllll}
\hline \multirow{2}{*}{ Site } & \multicolumn{3}{c}{ Base } & \multicolumn{3}{c}{ NopH } \\
\cline { 2 - 5 } & $r$ & RMSE & $r$ & RMSE \\
\hline Indonesia & 0.45 & 28.97 & 0.45 & 411.26 \\
Minnesota, USA & 0.57 & 27.92 & 0.57 & 162.43 \\
Michigan, USA & 0.09 & 76.29 & -0.08 & 201.00 \\
\hline
\end{tabular}

\subsection{Methane oxidation fraction in the rhizosphere}

Simulations suggest that the model tends to overestimate the magnitude of rhizospheric methane oxidation fraction at the two sites with measurements (Alberta, Canada and Florida, USA) (Fig. 7). With no change in aerenchyma transport, there are three ways to decrease the rhizospheric methane oxidation in the model: (1) decrease the maximum oxidation rate $\left(R_{o, \max }\right) ;(2)$ increase the $\mathrm{CH}_{4}$ half-saturation oxidation coefficient $\left(K_{\mathrm{CH}_{4}}\right)$; and (3) increase the $\mathrm{O}_{2}$ half-saturation oxidation coefficient $\left(K_{\mathrm{O}_{2}}\right)$. The values of these parameters are not well constrained, and measurements generally vary over two orders of magnitude (Riley et al., 2011). We found that the simulated methane flux responded similarly to the three parameters and was most sensitive to $R_{o \text {, max }}$. Therefore, we focused on $R_{o, \max }$ for our sensitivity analysis. We decreased $R_{O, \max }$ from $1.25 \mathrm{e}-5$ to $1.25 \mathrm{e}-6$, still within the estimated parameter uncertainty given in Riley et al. (2011), which led to a closer match of simulated rhizospheric methane oxidation fraction with observations in terms of magnitude (Fig. 7), although seasonal variations did not match well. This poor match in seasonal variation of methane fluxes between model and observation may be at least partially attributed to the fact that CLM4CN-derived HR peaks in early spring, not in summer when measured methane fluxes were highest (Fig. 7). We then tested the sensitivity of the global methane budget to this parameter and applied this lower $R_{O, \max }$ to the global simulation. The model estimated a $12 \%$ increase in global methane fluxes using the lower $R_{o, \max }$ (Table 7). We also note that there are predicted spring peaks in methane emissions at the Alberta (Canada) and Michigan (USA) sites that are not in the observations (Fig. 7). A detailed description of this phenomenon is provided in Appendix B (Fig. B1).

\subsection{Impacts of $\mathrm{pH}$ on methane emission}

There are three sites in our dataset for model testing that have $\mathrm{pH}$ values more acidic than neutral conditions, allowing us to test our $\mathrm{pH}$ function against observed methane fluxes. In each case, the site level $\mathrm{pH}$ is obtained from local measurements.

Soil $\mathrm{pH}$ plays an important role in constraining model simulations to the observations at several sites where soils are acidic (Fig. 8, Table 2). For example, at the Indonesian site, if we remove the $\mathrm{pH}$ impact, the model simulated methane emissions of $>300 \mathrm{mg} \mathrm{CH}_{4} \mathrm{~m}^{-2} \mathrm{~d}^{-1}$, which is $>30$ to 80 times larger than the measurements (approximately $10 \mathrm{mg} \mathrm{CH}_{4} \mathrm{~m}^{-2} \mathrm{~d}^{-1}$ ). Soil $\mathrm{pH}$ is also an important control on methane emissions at the Minnesota and Michigan sites. Removal of the $\mathrm{pH}$ factor at these sites increases the methane emissions by a factor of $4-5$. Including the $\mathrm{pH}$ 


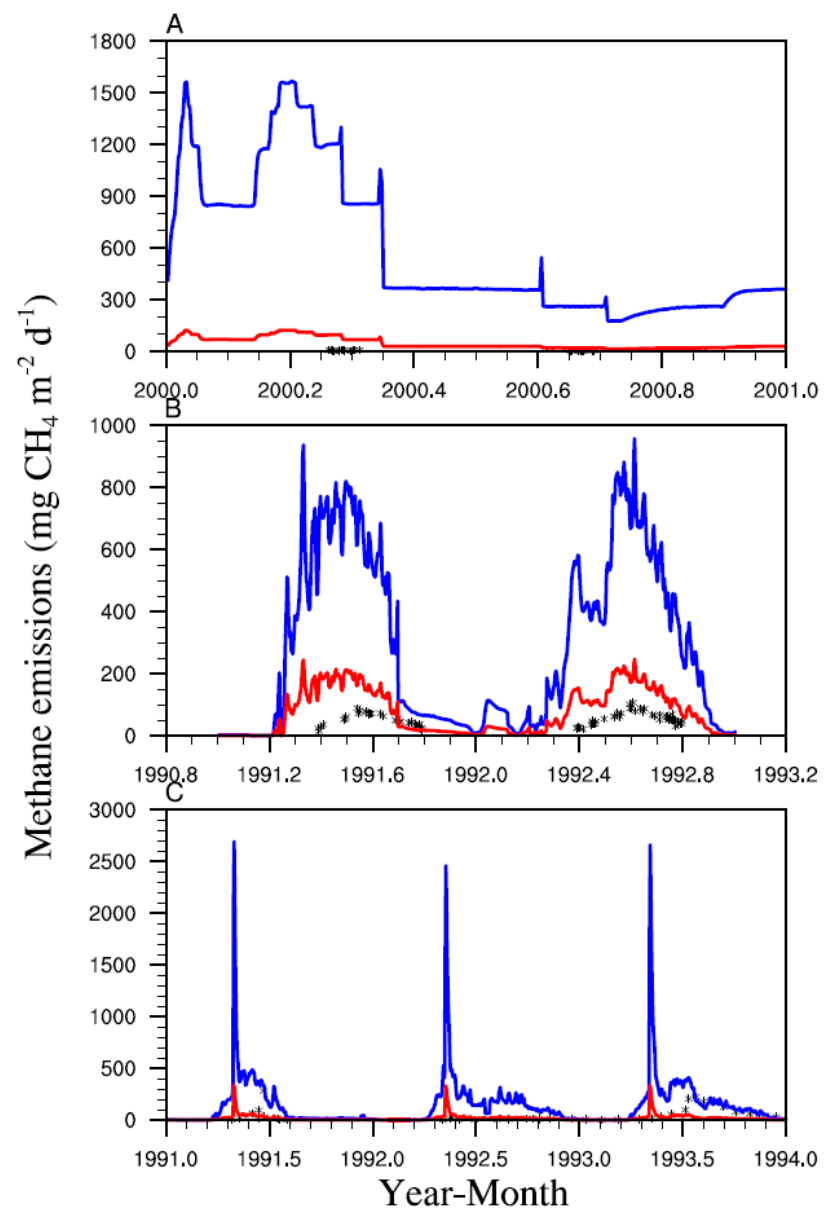

Fig. 8. Comparison between model simulations and observations at wetland sites. Red line indicates simulations with $\mathrm{f}_{\mathrm{pH}}$; Blue line shows simulations without $\mathrm{f}_{\mathrm{pH}}$. (A: Indonesia; B: Minnesota; C: Michigan). Observations are in dots. Please see Table 2 for site descriptions.

factor allows for better agreement with observations (Fig. 8). Table 3 shows that $f_{\mathrm{pH}}$ has reduced the RMSE at all sites, although $f_{\mathrm{pH}}$ has negligible impacts on the ability to simulate the seasonal cycle (seen in the correlation coefficient) (Table 3). These results suggest that $\mathrm{pH}$ is an important control on regional methane budgets, and should be included in models to produce accurate spatial distribution and magnitudes of methane emission. A scatter plot of simulated annual mean fluxes with and without $\mathrm{pH}$ function against observations is provided in Appendix C (Fig. C1).

\subsection{Impact of redox potential on methane emissions}

Our simulations suggest that redox potential does not have substantial impacts on methane emissions at the sites where we have observations of water table levels (not shown). This low sensitivity is because of the relatively small changes in observed water table fluctuation at these sites (for detailed

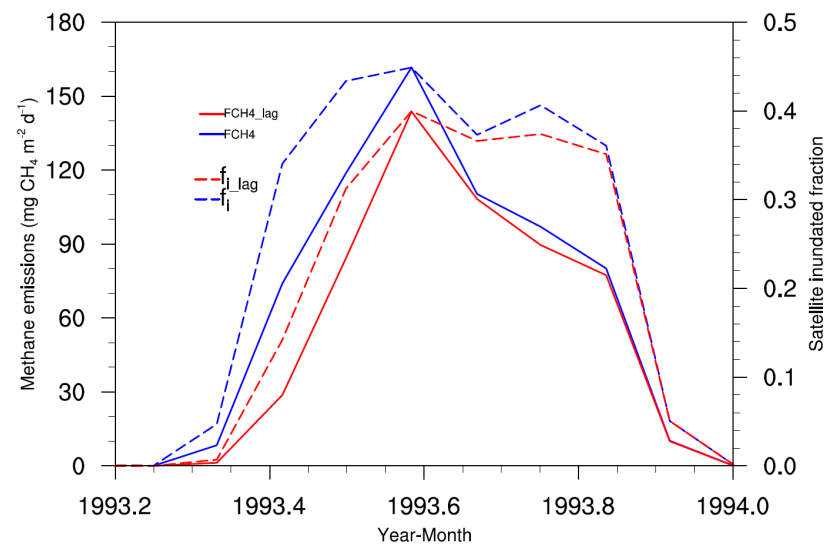

Fig. 9. Impact of redox potential on methane production and inundated fraction at a grid cell (lat:48.31 N, long:92.5 W) extracted from global simulation. Dashed lines indicate satellite inundated fraction ( $f_{i}$ in blue) and delayed inundated fraction $\left(f_{i_{-}}\right.$lag in red); Solid lines are methane emissions with (FCH4_lag in red) and without $\left(\mathrm{FCH}_{4}\right.$ in blue) the inclusion of redox potential impact.

information, see the description of each site given in the Table 2 references). At each individual site, the impact of redox potential on methane production is predominately through the change in water table positions. This dependence is different from the large-scale simulation where the impact of redox potential is largely seen through changes in the inundated fraction. In the large-scale simulation, the impact of redox potential in the unsaturated zone is through the change in water table positions and is negligible since very little methane is produced and released into the atmosphere. The redox potential factor does play an important role in largescale methane emissions when the inundated fraction at a grid cell dramatically changes from season to season. Figure 9 shows the impact of redox potential on methane emission at a grid cell near Michigan extracted from a global CLM4 simulation. These simulations suggest that modeled methane emissions are reduced due to the fact that the inundated fraction that produces methane $\left(f_{i_{-} \text {lag }}(t)\right.$,red dashed line) is much lower than the actual inundated fraction $\left(f_{i}(t)\right.$, blue dashed line). We emphasize that this proposed mechanism has not been tested against observations but matches theoretical expectations.

\subsection{Site simulations: rice paddies}

We simulated the rice paddies as single-grid cell cases and assumed that the fields were submerged during the simulation period between initial flooding and final drainage. In general, CLM4Me'(as modified for rice paddies) captures the magnitudes and temporal variations of methane emissions during the growing season (Fig. 10). In the model simulations, methane emissions have a large peak right after drainage in each simulation. This phenomenon is consistent with the measurements at sites in California and 


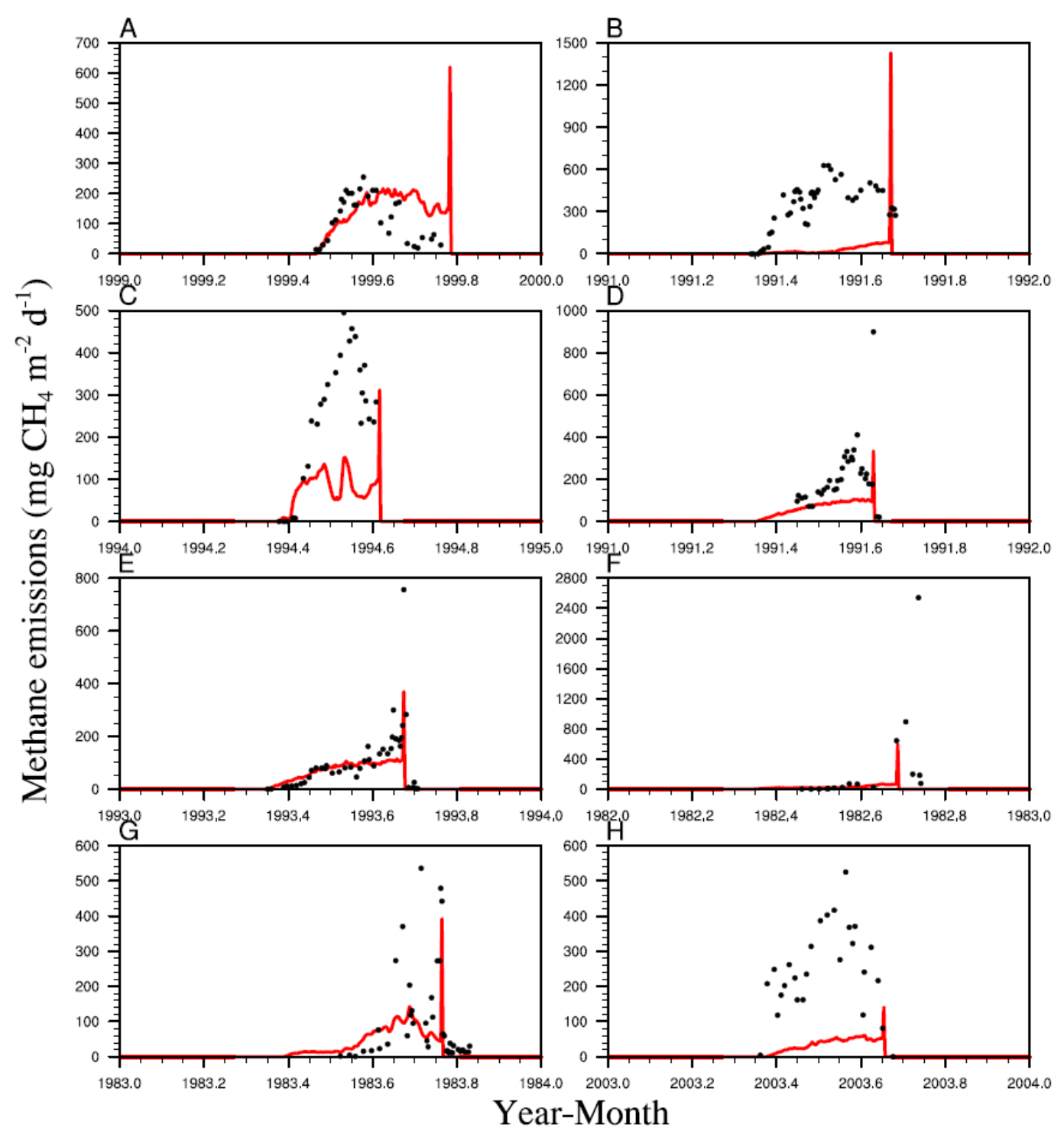

Fig. 10a. Comparison between modeled methane fluxes (red lines) and observation (dots) at each rice paddy site. Note that the scale of $y$-axis varies between plots. A: Nanjing, China; B: Italy; C:Texas, USA; D: Japan, 1991; E: Japan,1993; F: California, USA, 1982; G: California, USA, 1983; H: Chengdu, China. Please see Table 1 for site descriptions.

Japan (Fig. 10d-f), but not at the other sites, possibly due to the duration and frequency of measurements (i.e., once a week). The sudden increase in simulated methane emissions immediately after drainage can be attributed to the release of methane previously trapped in the soil and water. This flush of methane has also been demonstrated in other studies (Jain et al., 2000; Wassmann et al., 1994). On a growing-season mean basis, the model performed relatively well for sites with observed mean fluxes less than $200 \mathrm{mg}$ $\mathrm{CH}_{4} \mathrm{~m}^{-2} \mathrm{~d}^{-1}$, and less well for sites with greater than a mean of $200 \mathrm{mg} \mathrm{CH}_{4} \mathrm{~m}^{-2} \mathrm{~d}^{-1}$ (Fig. 11a). Simulated maximum $\mathrm{CH}_{4}$ emissions matched observations relatively well for sites with maximum daily fluxes less than $300 \mathrm{mg} \mathrm{CH}_{4} \mathrm{~m}^{-2} \mathrm{~d}^{-1}$, but less well for sites with values greater than about $300 \mathrm{mg}$ $\mathrm{CH}_{4} \mathrm{~m}^{-2} \mathrm{~d}^{-1}$ (Fig. 11b). For the latter sites, the model has a low bias.

\subsection{NPP-adjusted methane fluxes}

Scatter plots show that the NPP-based adjustment to simulated methane emissions only slightly increased the correlation with the measurements and did not improve the RMSE (Fig. 11). For instance, the correlation between CLM4Me' and MODIS-derived mean fluxes increased from 0.5 to 0.61 using the NPP-based adjustment, primarily due to the adjustment at the Panama site (Fig. 11a). Overall, adjusting for NPP did not significantly improve model simulations 


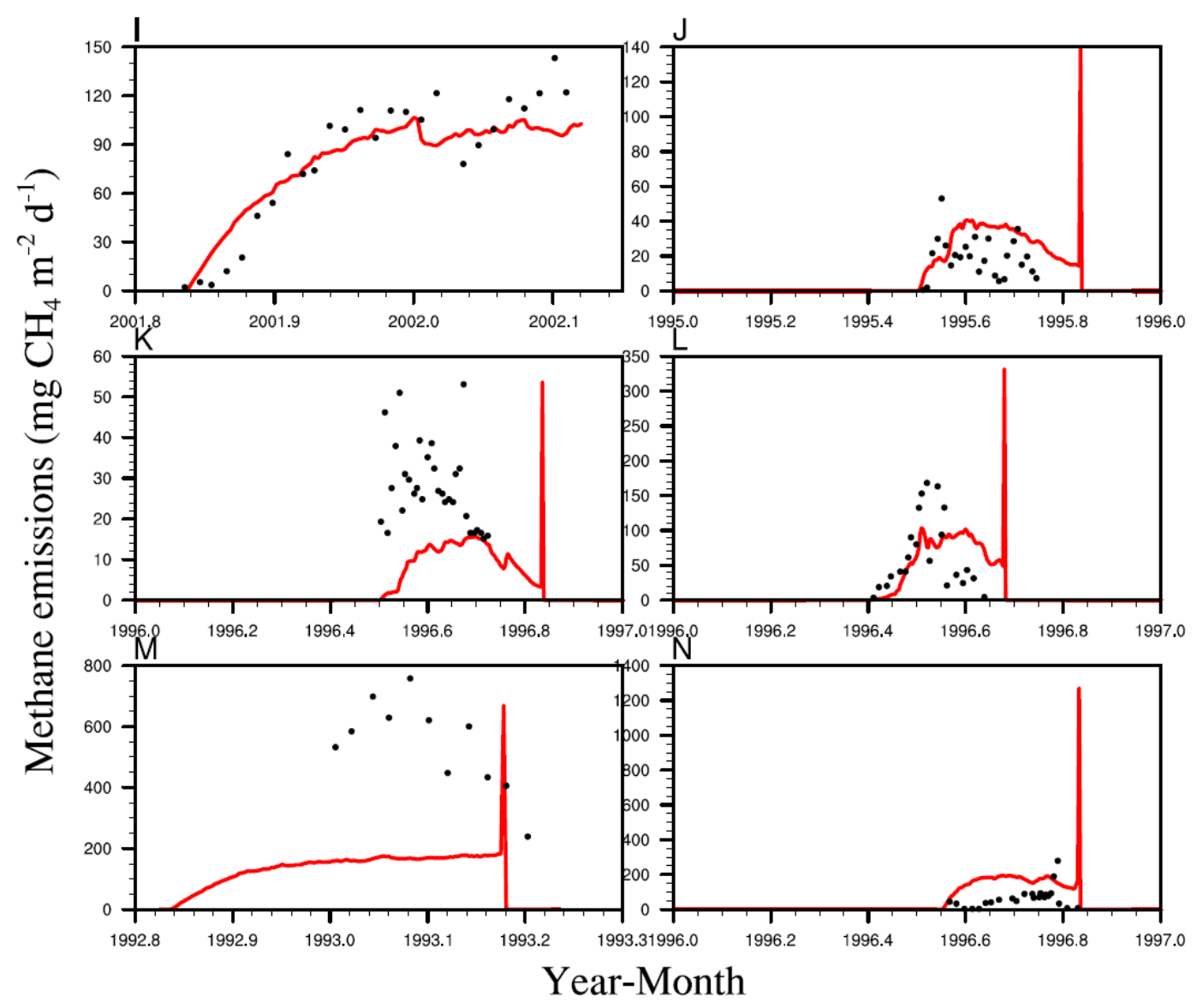

Fig. 10b. (continued). I: Central Java, Indonesia; J: New Delhi, India, 1995; K: New Delhi, India, 1996; L: Beijing, China; M: Lampung, Indonesia; N: Cuttack, Indonesia. Please see Table 1 for site descriptions.

at all other sites. This result suggests that the methane emission model biases are not just because of errors in the NPP. However, biases in modeled NPP would likely change the distribution of the global methane emissions and impact the regional methane budget as discussed in greater detail in Sect. 5.1.

\subsection{Global simulations vs. observations}

We note that our global simulations were forced with satellite inundation data and the same NCEP forcing data as used for the site simulations. To compare the global simulation against site level measurements, we extracted methane fluxes from the saturated portion of the closest grid cells to both the natural wetlands and rice paddies in the global simulation and compared with site level observations. This is the best comparison one can do usually for a global simulation (e.g., Riley et al., 2011), and thus a commonly used approach. We used methane fluxes from the saturated portion because they are very close to site-level conditions where the water table level is close to the surface, as is the case at most of the sites.
Comparison between mean methane fluxes in the global simulation and observations at sites shows a poor correlation $(r=0.2)$ (Fig. 12). Comparing with Fig. 11 suggests that the model's performance is worse in simulating the magnitude of methane fluxes when comparing grid-cell methane fluxes obtained from global simulations with point measurements. For instance, the correlation $(r)$ decreased and the RMSE increased in Fig. 12. This result is not unexpected because of spatial heterogeneity and the large spatial resolution $\left(1.9^{\circ} \times 2.5^{\circ}\right.$ resolution $)$ used in the global simulation. We suggest that the model should be tested at the site level if localized information is available, ideally forced by local vegetation characteristics, water table depth, and nearsurface meteorology.

\subsection{Sensitivity analysis at individual sites}

Seven parameters were selected for sensitivity analysis (Table 4). The value for each parameter was varied from the lower end to the higher end of its range in the references listed in Table 4 to test its impacts on modeled methane emissions. The Panama site was selected for this analysis. The 
Table 4. Parameters used for sensitivity test.

\begin{tabular}{|c|c|c|c|c|c|}
\hline Parameter & Description & Value used & Units & Range & References \\
\hline$f_{\mathrm{CH}_{4}}$ & $\mathrm{CH}_{4} / \mathrm{CO}_{2}$ & 0.2 & & $0.001-1.7$ & Segers (1998) \\
\hline$p$ & Porosity of tillers & 0.3 & & $0.08-0.43$ & Colmer (2003) \\
\hline$Q_{10}$ & $\mathrm{Q}_{10}$ for $\mathrm{CH}_{4}$ production & 3 & & $1.5-26$ & Segers (1998) \\
\hline$R_{o, \max }$ & Maximum oxidation rate & 45 & $\mu \mathrm{M} \mathrm{h}^{-1}$ & $5.0-50.0$ & $\begin{array}{l}\text { Dunfield et al. (1993); } \\
\text { Knoblauch (1994) }\end{array}$ \\
\hline$K_{\mathrm{CH}_{4}}$ & $\mathrm{CH}_{4}$ half-saturation oxidation coefficient & 5 & $\mu \mathrm{M}$ & $1.0-5.0$ & $\begin{array}{l}\text { Walter and } \\
\text { Heimann (2000); } \\
\text { Knoblauch (1994) }\end{array}$ \\
\hline$Q_{o, 10}$ & Q10 oxidation constant & 1.9 & & $1.4-2.1$ & Knoblauch (1994) \\
\hline$K_{O 2}$ & $\mathrm{O}_{2}$ half-saturation oxidation coefficient & 20 & $\mu \mathrm{M}$ & $17-25$ & $\begin{array}{l}\text { Lidstrom and } \\
\text { Somers (1984) }\end{array}$ \\
\hline$C_{e, \max }$ & $\mathrm{CH}_{4}$ concentration to start ebullition & 0.15 & & $0.12-0.15$ & $\begin{array}{l}\text { Kellner et al. (2006); } \\
\text { Baird et al. (2004) }\end{array}$ \\
\hline
\end{tabular}

percentage change in annually averaged methane emission rate relative to the base simulation is listed in parentheses in Table 5 for each parameter. The $\mathrm{Q}_{10}$ for production, $f_{\mathrm{CH}_{4}}$, and the porosity of tillers have the most significant impacts on simulated methane emissions at this site. In particular, $f_{\mathrm{CH}_{4}}$ has direct impacts on total methane production and this parameter is not well constrained and it varies from 0.001 to 1.7 (Table 4) in the literature (Wania et al., 2010). The default value used (0.2) is consistent with other models (such as Wania et al. (2010)). Q10 also has an important impact on methane production, and its value ranges from 1.7 to 16 in the literature (see Table 4), although these values are probably biased by variations in redox potential, as discussed in Rilery et al. (2011). We chose a $Q_{10}$ value of 3 as our base value, which is the same as used in Zhang et al. (2002), but is different from that used in Riley et al. (2011). The model's strong sensitivity to these three parameters is consistent with the sensitivity analysis conducted by Wania et al. (2010) and Riley et al. (2011). The maximum oxidation rate $\left(R_{o, \max }\right)$ has a moderate impact on regional methane emissions. Other parameters, including $K_{\mathrm{CH}_{4}}, Q_{o, 10}, K_{O 2}$, and $C_{e, \max }$, have the smallest influences on methane emissions. For instance, varying $C_{e, \max }$ values within the range of current estimates negligibly affects methane emissions. Sensitivity analysis conducted at several other sites shows similar results (not shown).

\subsection{Sensitivity analysis on the global methane budget from natural wetlands}

In this section, we focus our analysis on wetland emissions. For this sensitivity analysis, we conducted two-yr (19921993) simulations and used the second year for this analysis. We conducted the sensitivity analysis with the follow- ing parameters: soil $\mathrm{pH}\left(f_{\mathrm{pH}}\right)$, redox potential $\left(f_{\mathrm{pE}}\right)$, and the limitation on aerenchyma area $\left(f_{\text {aere }}\right)$. The processes these parameters represent have very different impacts on the global methane budget. We note that uncertainties in model structure and other model parameters listed in Table 4 could also have significant impacts on global emissions. These uncertainties have been discussed in Riley et al. (2011) and are not included in this paper.

In general, the inclusion of soil $\mathrm{pH}\left(f_{\mathrm{pH}}\right)$ and redox potential $\left(f_{\mathrm{pE}}\right)$ decreased methane emissions. The limitation on aerenchyma area $\left(f_{\text {aere }}\right)$ decreased methane oxidation, causing an increase in methane emissions. Model results suggest that the impacts of these factors on the global and regional methane budget vary (Fig. 13). Soil $\mathrm{pH}$ has the largest impacts on methane emissions. On the global scale, exclusion of soil $\mathrm{pH}$ in methane production $\left(f_{\mathrm{pH}}=1.0\right)$ increased methane emissions by $100 \mathrm{Tg} \mathrm{CH}_{4} \mathrm{yr}^{-1}$, an approximate $41 \%$ increase from the base simulation (Table 7). Removal of redox potential impacts $\left(f_{\mathrm{pE}}=1.0\right)$ increases global methane emissions to $290 \mathrm{Tg} \mathrm{CH}_{4} \mathrm{yr}^{-1}$ (a $18 \%$ increase from the base simulation). Unlimited aerenchyma $\left(f_{\text {aere }}=1.0\right)$ only decreased the global methane budget by $3 \%$. At the regional scales, approximately $70 \%$ of the global impacts of these factors occurred in the tropics (Fig. 13a), as tropical regions account for $80 \%$ of the global methane wetland emissions and soil $\mathrm{pH}$ is generally low there (Fig. 5). As discussed in Sect. 4.2, $R_{o, \max }$ is also an important variable (Fig. 5).

Our simulations suggest that the rhizospheric methane oxidation fraction is generally higher in temperate regions and lower in the tropics and high latitudes (Fig. 13b). The rhizospheric oxidation fraction is approximately $11 \%, 25 \%$, and $23 \%$ in the tropics, temperate, and high latitudes, respectively. On the global scale, $\sim 15 \%$ of methane was oxidized 
Table 5. Results from sensitivity test for the Panama site. Percentage values in parentheses are relative to the simulations using the base values.

\begin{tabular}{lllll}
\hline Parameter & Description & low & high & base value \\
\hline$f_{\mathrm{CH}_{4}}$ & $\mathrm{CH}_{4} / \mathrm{CO}_{2}$ ratio & $0.1(-53.4 \%)$ & $0.3(58.5 \%)$ & 0.2 \\
\hline $\mathrm{p}$ & Grass aerenchyma porosity & $0.1(+30 \%)$ & $0.43(-49.6 \%)$ & 0.3 \\
$Q_{10}$ & $\mathrm{Q}_{10}$ for $\mathrm{CH}_{4}$ production & $1.5(-41.9 \%)$ & $5(+11 \%)$ & 3 \\
$R_{O, \max }$ & Maximum oxidation rate & $5(36.1 \%)$ & $50(-1.7 \%)$ & 45 \\
$K_{\mathrm{CH}_{4}}$ & $\mathrm{CH}_{4}$ half-saturation oxidation coefficient & $1(-5.57 \%)$ & $10(+5.22 \%)$ & 5 \\
$Q_{o, 10}$ & $\mathrm{Q}_{10}$ for $\mathrm{CH}_{4}$ oxidation & $1.4(7.1 \%)$ & $2.4(-5.1 \%)$ & 1.9 \\
$K_{\mathrm{O}_{2}}$ & $\mathrm{O}_{2}$ half-saturation oxidation coefficient & $17(-0.6 \%)$ & $25(0.867 \%)$ & 20 \\
$C_{e, \text { max }}$ & $\mathrm{CH}_{4}$ concentration to start ebullition & $0.13(0 \%)$ & $0.17(0 \%)$ & 0.15 \\
\hline
\end{tabular}
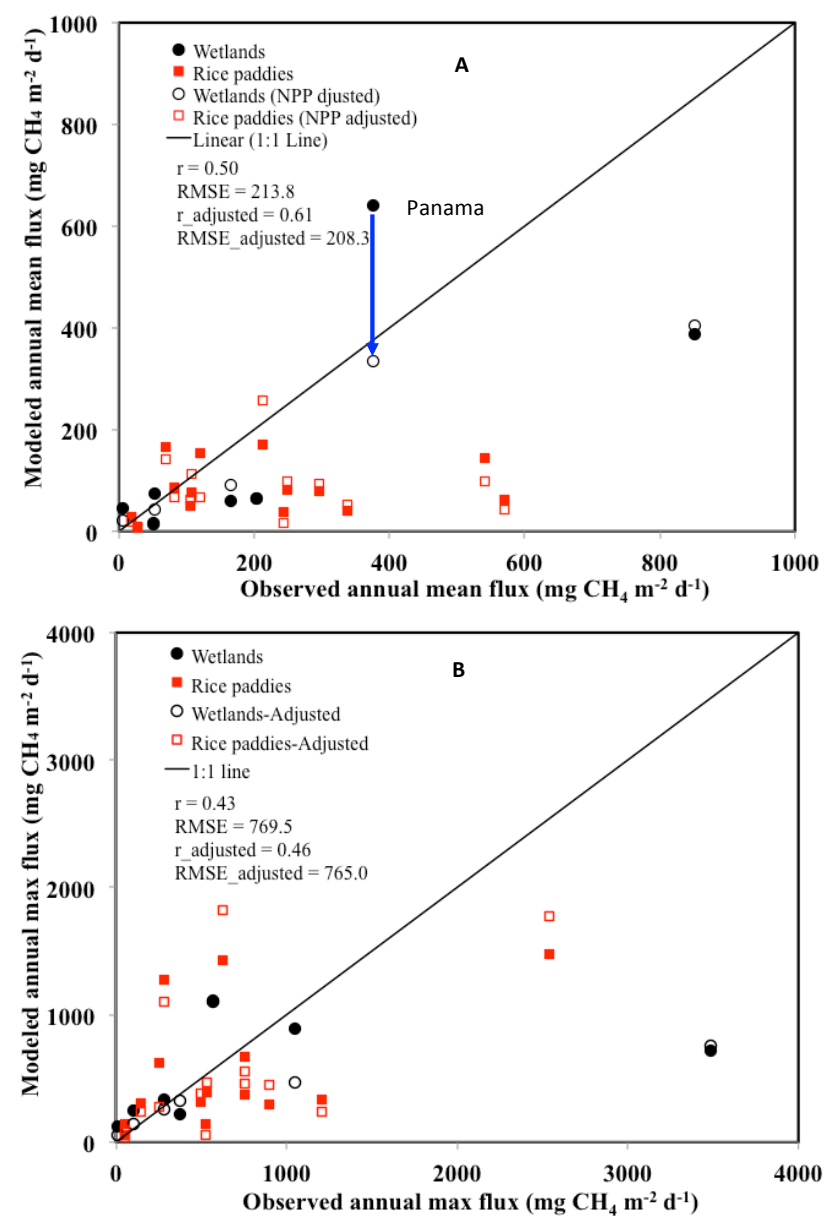

Fig. 11. Scatter plot of observed and model (and NPP adjusted) simulated annual mean (top) and annual maximum of the daily averaged (bottom) methane emissions $\left(\mathrm{mg} \mathrm{CH}_{4} \mathrm{~m}^{-2} \mathrm{~d}^{-1}\right)$ at the rice paddies and wetlands.

before being transported through aerenchyma and eventually being released to the atmosphere. Although aerenchyma is well known in grasses, some wetland trees also develop conduits (Grosse et al., 1992). The default value for aerenchyma

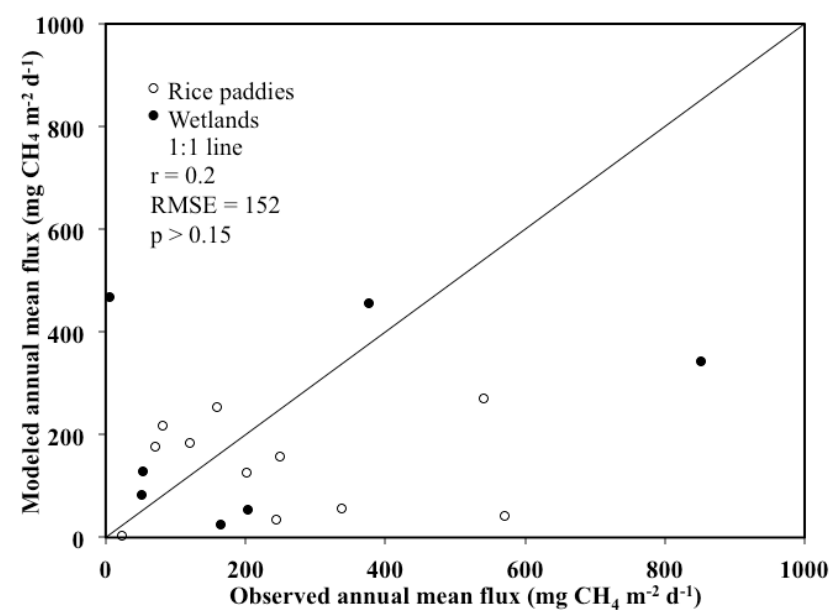

Fig. 12. Comparison of mean methane fluxes $\left(\mathrm{mg} \mathrm{CH}_{4} \mathrm{~m}^{-2} \mathrm{~d}^{-1}\right)$ extracted from the closest grid cells in the global simulation with observations at sites. We found a poor correlation between them possibly due to the spatial heterogeneity and large spatial resolution in the global simulation and other errors associated with this model.

in trees is set to be $17 \%$ of that in grasses. Adjusting this proportion from $1 \%$ to $35 \%$ changed the methane flux by less than $25 \mathrm{Tg} \mathrm{CH}_{4} \mathrm{yr}^{-1}$ ( $<10 \%$ of global methane budget).

\subsection{Fine root carbon (FROOTC) vs. leaf area index (LAI)}

Our modeling results suggest that the simulated global methane budget is very sensitive to the way the aerenchyma area is calculated (Table 7). When the aerenchyma area is calculated based on FROOTC using Eq. (11) in this paper, the model's methane emissions are $245 \mathrm{Tg} \mathrm{yr}^{-1}$. When LAI is used to calculate aerenchyma area, the methane emissions are $150 \mathrm{Tg} \mathrm{yr}^{-1}$, an approximately $39 \%$ decrease relative to using FROOTC. At the regional scale, using LAI leads to a $39 \%, 68 \%$, and $32 \%$ decrease in methane emissions from high latitudes, mid-latitude, and tropics, respectively, relative to FROOTC method. Since tropical emissions are 

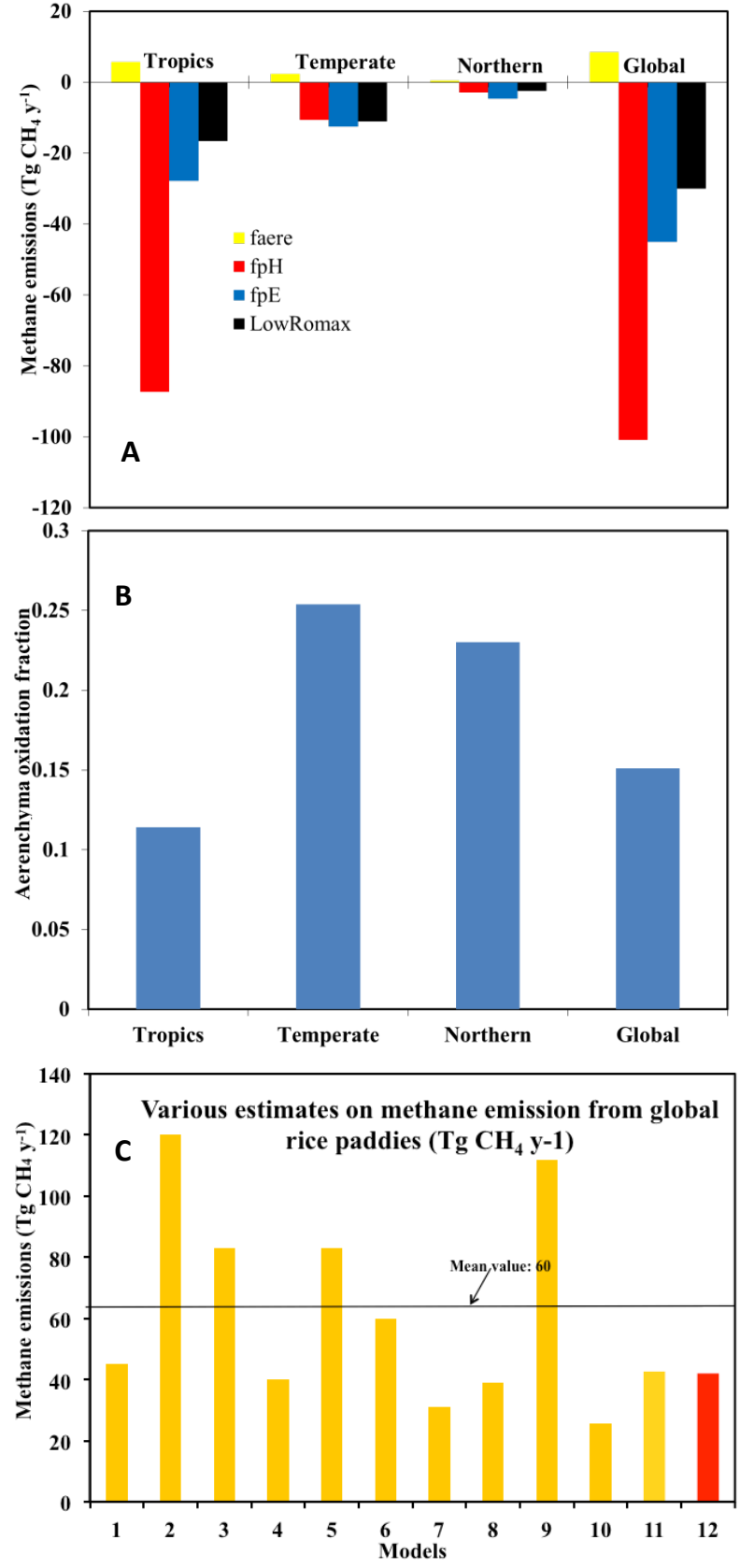

Fig. 13. A: Sensitivity analysis of each variable. The number on the y-axis indicates the change in net annual mean methane emission associated with changes in each variable. B: Prognostic aerenchyma oxidation fractions at different regions. C: Comparison of global methane budget from rice paddies estimated in our model and other models. 1: Seiler et al. (1984); 2: HolzapfelPschorn and Seiler (1986); 3: Bouwman (1990); 4: Sass (1994); 5: Hein et al. (1997); 6: Wuebbles and Hayhoe (2000); 7: Scheehle et al. (2002); 8: Olivier et al. (2005); 9: Chen and Prinn (2006); 10: Yan et al. (2009); 11: Spahni et al. (2011); 12: this model (red). substantially larger than high latitude emissions, using LAI decreases the absolute difference between the tropical and high latitude emissions. We note that, although fine root density is expected to be a better proxy for aerenchyma area, the current version of CLM4 does not explicitly represent wetland plants and their fine-root $\mathrm{C}$ content, nor has the predicted fine-root $\mathrm{C}$ content of non-wetland plants, or its relationship with aerenchyma area, been tested. Therefore, the calculation of wetland plant dynamics and aerenchyma area remains an important source of $\mathrm{CH}_{4}$ emission error in the model.

\section{Estimation of global methane flux}

\subsection{Global simulations-wetlands}

We estimated global wetland methane emissions of $256 \mathrm{Tg} \mathrm{CH}_{4} \mathrm{yr}^{-1}$ (including global soil losses) which is close to the estimate of Walter et al. (2001), Riley et al. (2011), and Mikaloff Fletcher et al. (2004), but higher than other estimates (Aselmann and Crutzen, 1989; Bartlett et al., 1990; Bartlett and Harriss, 1993; Fung et al., 1991; Chen and Prinn, 2006; Spahni et al., 2011; Bousquet et al., 2006) (Table 6). Sensitivity analysis suggests a large range (150$346 \mathrm{Tg} \mathrm{CH}_{4} \mathrm{yr}^{-1}$ ) in the annual methane flux to the processes described in this study. The IPCC AR4 (2007, WG1 7.4.1.1) (Denman et al., 2007) suggests the total error uncertainty in global methane loss can be estimated as $\pm 15 \%$ or $87 \mathrm{Tg} \mathrm{yr}^{-1}$. The AR4 (2007, WG1 7.4.1.1) (Denman et al., 2007) also suggests estimates of anthropogenic sources range between 264 and $428 \mathrm{Tg} \mathrm{yr}^{-1}$. Thus, while wetland emissions of $256 \mathrm{Tg} \mathrm{CH}_{4} \mathrm{yr}^{-1}$ obtained here are on the high end of published estimates, they are within the uncertainty of the global budget. We note that the inverse study of Mikaloff Fletcher et al. (2004) is able to balance the global budget of methane with a wetland source of $231 \mathrm{Tg} \mathrm{yr}^{-1}$, close to our central estimate.

Figure 14 shows the spatial distribution of mean methane flux for the period 1993-2004 from natural wetlands. Tropical wetlands released $201 \mathrm{Tg} \mathrm{CH}_{4} \mathrm{yr}^{-1}$ to the atmosphere, which comprises $78 \%$ of the global methane budget. On the other hand, CLM4Me' high latitude $(>50 \mathrm{~N})$ (or northern latitude $(>45 \mathrm{~N})$ ) wetlands released $\sim 12 \mathrm{Tg} \mathrm{CH}_{4} \mathrm{yr}^{-1}$ (or $\sim 15 \mathrm{Tg} \mathrm{CH}_{4} \mathrm{yr}^{-1}$ ). A comparison of the global methane emissions between CLM4Me' and other models is in Fig. 15 (Bartlett and Harriss, 1993; Cao et al., 1996; Aselmann and Crutzen, 1989; Matthews and Fung, 1987; Bartlett et al., 1990; Walter et al., 2001; Bousquet et al., 2006; Riley et al., 2011). A number of notable features stand out in the comparison of CLM4Me' to other models: (i) the CLM4Me' estimate is at the low end of current estimates for high latitude wetlands; (ii) it is at the high end for tropical and temperate wetlands. We address the estimates of CLM4Me' at northern latitudes first. For northern latitude regions ( $>45 \mathrm{~N})$, CLM4Me' simulates $15 \mathrm{Tg} \mathrm{CH}_{4} \mathrm{yr}^{-1}$ 

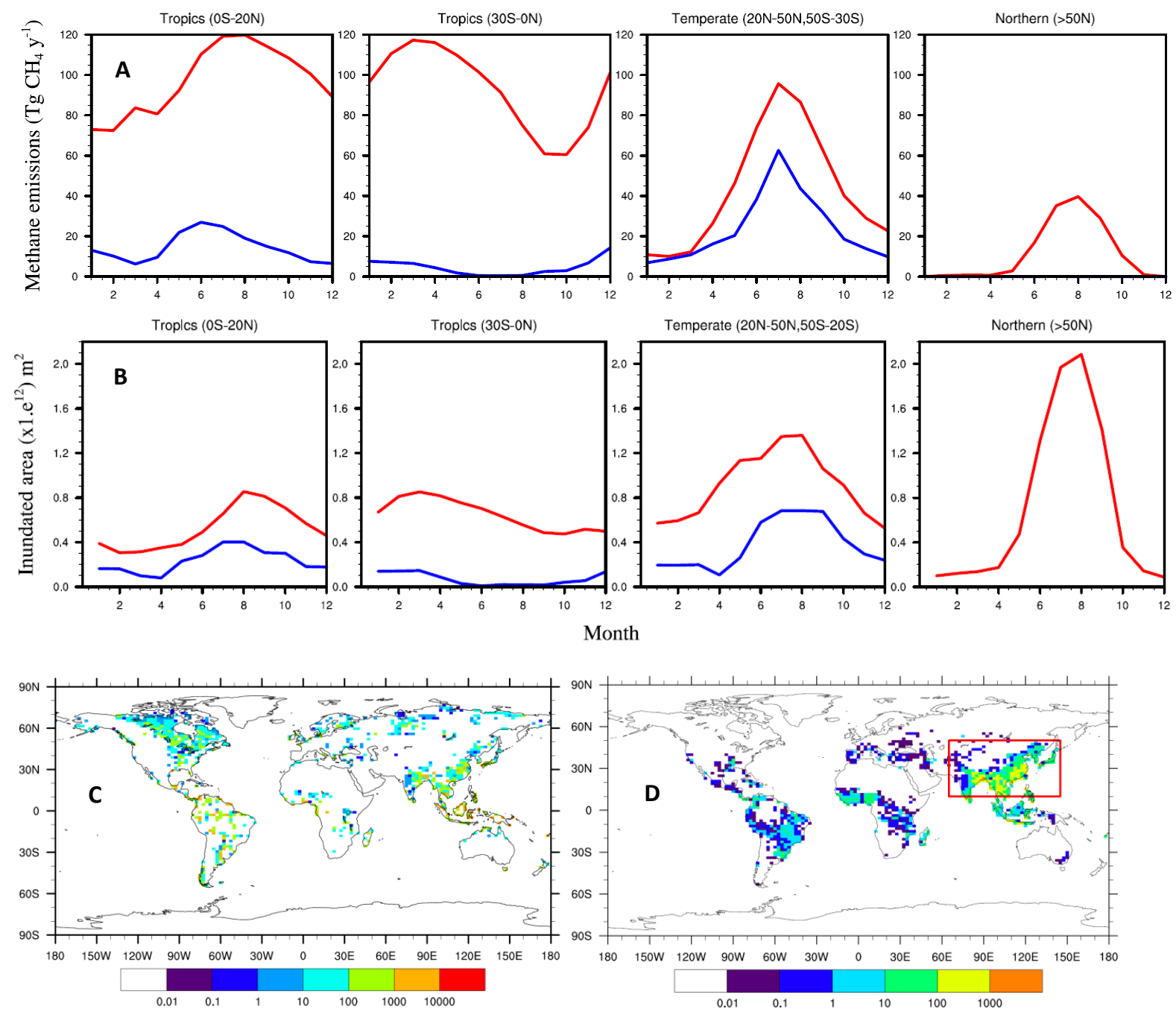

Fig. 14. Seasonal variation of methane emissions (A) and inundated areas (B) in the four defined regions for natural wetlands (red) and rice paddies (blue). (C): The global distribution of the mean methane emission rates (units: $\mathrm{mg} \mathrm{CH}_{4} \mathrm{~m}^{-2} \mathrm{~d}^{-1}$ ) during the period 1993-2004 from natural wetlands. (D): The global distribution of annual averaged methane emissions (units: $\mathrm{mg} \mathrm{CH}_{4} \mathrm{~m}^{-2} \mathrm{~d}^{-1}$ ) for the year 2000 from rice paddies. (Asian monsoon regions are in red box).

released into the atmosphere. This value is lower than the estimates using various process-based models (31$106 \mathrm{Tg} \mathrm{CH}_{4} \mathrm{yr}^{-1}$ ) (Cao et al., 1996; Walter et al., 2001; Zhuang et al., 2004; Wania et al., 2010; Spahni et al., 2011; Ringeval et al., 2010; Riley et al., 2011) (Table 6), but is close to the lower end estimate of Chen and Prinn (2006) in an inverse calculation, where tropical and southern wetlands account for $70 \%$ of the global emissions. Accounting for a methane uptake of $6.9 \mathrm{Tg} \mathrm{CH}_{4} \mathrm{yr}^{-1}$ (Wania et al., 2010), methane emissions from northern wetlands in Chen and Prinn's inverse model give 21.9-57.9 $\mathrm{Tg} \mathrm{CH}_{4} \mathrm{yr}^{-1}$. Denman et al. (2007) suggest that a number of more recent topdown studies from observations and isotope ratios suggest greater emissions in tropical regions than found previously and lower emissions at high latitudes. In fact, the recent in- verse study of Spahni et al. (2011) found the posteriori emissions in the northern peatlands (north of $45^{\circ}$ ) decreased by approximately $25 \%$ from their a priori values (from 38.6 to $28.2 \mathrm{Tg} \mathrm{CH}_{4} \mathrm{yr}^{-1}$ ). The a priori values were taken from the LPJ-WhyMe emission model (Wania et al., 2010).

The inverse study of Kim et al. (2011) estimated a methane emission of $3.0 \mathrm{Tg} \mathrm{CH}_{4} \mathrm{yr}^{-1}$ from West Siberian wetlands (much lower than the GISS inventory estimation of $6.3 \mathrm{Tg} \mathrm{CH}_{4} \mathrm{yr}^{-1}$ ). West Siberian wetlands comprise approximately $30 \%$ of the high latitude wetlands. Bottom-up estimates of methane emissions from the Canadian wetlands (Bachand et al., 1996) are $3.5 \mathrm{Tg} \mathrm{CH}_{4} \mathrm{yr}^{-1}$. Canadian wetlands comprise $40 \%$ of the high latitude wetlands (Rydin and Jeglum, 2006). Thus accounting for $70 \%$ of the high latitude wetland emissions, these studies estimate the Canadian 
Table 6. Comparison of global wetland methane estimates between our model and other models.

\begin{tabular}{|c|c|c|c|c|}
\hline \multirow[t]{2}{*}{ Model } & \multicolumn{3}{|c|}{ Climate zone } & \multirow{2}{*}{$\begin{array}{l}\text { Total global } \\
\text { budget }\end{array}$} \\
\hline & $\begin{array}{l}\text { Northern } \\
(>50 \mathrm{~N})\end{array}$ & $\begin{array}{l}\text { Temperate } \\
(20-50 \mathrm{~N}, 30 \mathrm{~S}-50 \mathrm{~S})\end{array}$ & $\begin{array}{l}\text { Tropical } \\
(20 \mathrm{~N}-30 \mathrm{~S})\end{array}$ & \\
\hline Matthews and Fung (1987) & 65 & 14 & 32 & 111 \\
\hline Aselmann and Crutzen (1989) & 25 & 12 & 43 & 80 \\
\hline Bartlett et al. (1990) & 39 & 17 & 55 & 111 \\
\hline Bartlett and Harriss (1993) & 34 & 5 & 66 & 105 \\
\hline Cao et al. (1996) & 23.4 & 17.2 & 51.4 & 92 \\
\hline Walter et al. (2001) & 48 & 26 & 186 & 260 \\
\hline Zhuang et al. (2004) & $57.3^{*}$ & N/A & N/A & \\
\hline Wania et al. (2010) & $57.2^{*}$ & N/A & N/A & \\
\hline Bousquet et al. (2006) & 31.55 & 25 & 103 & 159.55 \\
\hline Chen and Prinn (2006) & $21.9-57.9 *$ & & & \\
\hline Ringeval et al. (2010) & 40.8 & 51 & 102 & 193.8 \\
\hline Spahni et al. (2011) & $28.2 *$ & & & \\
\hline Riley et al. (2011) & $70 *$ & 50 & 160 & 270 \\
\hline This model & $12(15 *)$ & 43 & 201 & 256 \\
\hline
\end{tabular}

* for northern latitude $>45 \mathrm{~N}$.

Table 7. Global methane budget for different case simulations for year 1993.

\begin{tabular}{llll}
\hline Simulation & Global budget & Percentage change & Description \\
\hline Base & 245 & $0 \%$ & All features are included \\
NoRedox & 290 & $18 \%$ & Same as Base, except $f_{\mathrm{pE}}=1.0$ \\
NopH & 346 & $41 \%$ & Same as Base, except $f_{\mathrm{pH}}=1.0$ \\
LowR ${ }_{o, \max }$ & 275 & $12 \%$ & Same as Base, except $R_{o, \text { max }}=1 / 10$ default value \\
NoLimitAeren & 237 & $-3 \%$ & Same as Base, except $f_{\text {aere }}=1.0$ \\
UseLAI & 150 & $-39 \%$ & Same as Base, except that LAI is used in calculation of aerenchyma area \\
\hline
\end{tabular}

and West Siberian wetlands to emit $6.8 \mathrm{Tg} \mathrm{CH}_{4} \mathrm{yr}^{-1}$. Assuming that other northern wetlands have similar methane emissions as Canadian and West Siberian wetlands would add another $3 \mathrm{TgCH}_{4} \mathrm{yr}^{-1}$ for a total of approximately $10 \mathrm{Tg} \mathrm{CH}_{4} \mathrm{yr}^{-1}$. Walter et al. (2006) estimated an emission of $3.8 \mathrm{Tg} \mathrm{CH}_{4} \mathrm{yr}^{-1}$ from melt lakes in Siberia that might also appear as inundated land giving an estimated total methane emission from northern high latitudes as approximately $14 \mathrm{Tg} \mathrm{CH}_{4} \mathrm{yr}^{-1}$, similar to our simulated value.

The high latitude fluxes in this study are likely lower than previous studies for several reasons. First, incorporating the impacts of soil $\mathrm{pH}\left(\mathrm{f}_{\mathrm{pH}}\right)$, redox potential $\left(f_{\mathrm{pE}}\right)$, high $\mathrm{Q}_{10}(3)$, and LowR $\mathrm{R}_{o \text {, max }}$ into the model simulation results in a $19 \%$, $28 \%, 50 \%$, and $17 \%$ decrease in the methane flux in the high latitudes, a rather modest impact (Fig. 13a). However, the reductions due to the $\mathrm{pH}$ and redox are physical processes that should not be neglected. The second reason that accounts for the low flux estimates is that the satellite data suggest the inundated land fraction is lower than previous estimates (Fig. 4). However, Prigent et al. (2007) demonstrate that the underestimation of inundated wetland for $50-60^{\circ} \mathrm{N}$ to $30-100^{\circ} \mathrm{E}$ region might be large because the satellite data do not capture a very large number of pixels with less than $10 \%$ water coverage in this region (see their Fig. 4). A sensitivity analysis suggests that high latitude $(>50 \mathrm{~N})$ methane fluxes will increase from $\sim 12$ to $19 \mathrm{Tg} \mathrm{CH}_{4} \mathrm{yr}^{-1}$ if inundated areas are increased by $37 \%$ using our base parameters. The considerable uncertainty in the wetland extent in the high latitudes (Papa et al., 2010; Finlayson et al., 1999) introduces a considerable uncertainty in high latitude methane fluxes. The third reason the high latitude emissions calculated here are less than in many previous studies is that the CLM4CN under-predicts high latitude vegetation productivity and soil carbon storage (Lawrence et al., 2011).

The northern latitude $\left(>45^{\circ} \mathrm{N}\right)$ methane flux predicted in CLM4Me (Riley et al., 2011) is $70 \mathrm{Tg} \mathrm{CH}_{4} \mathrm{yr}^{-1}$, which is much higher than our estimates. The differences between these slightly different model versions are due to several reasons: (1) The mean inundated fraction in Riley et al. (2011) is approximately $20 \%$ higher than the satellite inundated area used in this study; (2) Riley et al. (2011) excluded several features used in this study including $f_{\mathrm{pH}}$ and $f_{\text {aere }}$; (3) Riley et al. (2011) used a $Q_{10}$ of 2 for their base simulation while we used a $\mathrm{Q}_{10}$ of 3 (see Sect. 4.8); Our global sensitivity 

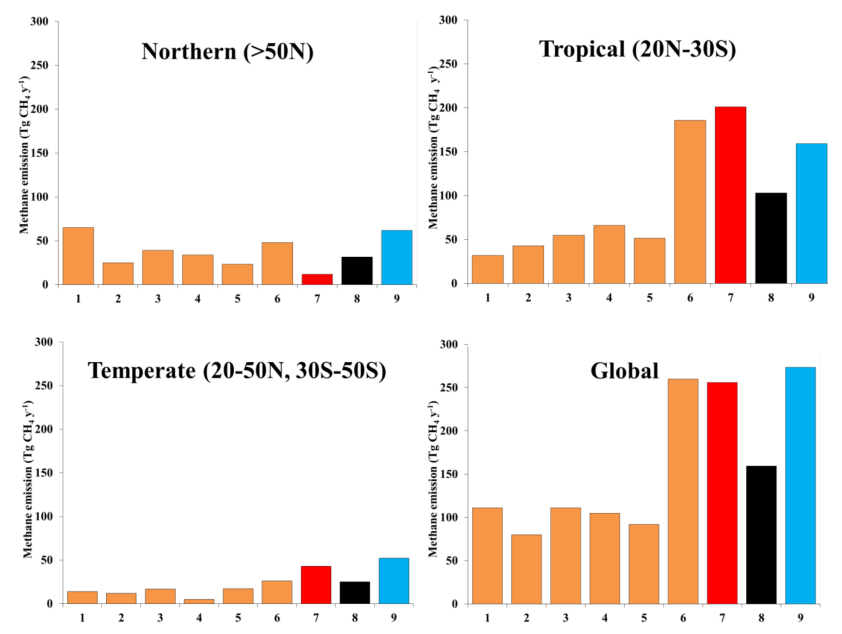

Fig. 15. Comparison of total $\mathrm{CH}_{4}$ emissions $\left(\mathrm{Tg} \mathrm{CH}_{4} \mathrm{yr}^{-1}\right)$ between our model and other models' estimations from natural wetlands. 1: Matthews and Fung (1987), 2: Aselmann and Crutzen (1989), 3: Bartlett et al. (1990), 4: Bartlett and Harriss (1993), 5: Cao et al. (1996), 6: Walter et al. (2001), 7: the CLM4Me' (this study), 8: Bousquet et al. (2006); 9: the CLM4Me model (Riley et al., 2011). Red indicates the CLM4Me' and Black is a top-down inversion. Please note that estimates from the $\mathrm{CH} 4 \mathrm{Me}$ (9) may include rice paddy emissions since the rice paddy fraction was not removed from model-simulated inundated fraction. Also, soil sink is included in the CLM4Me' and CLM4Me, but is excluded in other studies.

analysis indicates that using a $\mathrm{Q}_{10}$ of 2 will increase methane flux from high latitudes $(>50 \mathrm{~N}$ ) by $80 \%$ (increases from 12 to $22 \mathrm{Tg} \mathrm{CH}_{4} \mathrm{yr}^{-1}$ ) and decrease methane flux from tropics by $22 \%$ for the year 1993. Riley et al. (2011) also conducted this sensitivity analysis (see their Fig. 9) and showed a factor of 2 reduction going from $\mathrm{Q}_{10}=2$ to 3 , which is consistent with our sensitivity analysis.

For middle-latitude regions, the CLM4Me' estimate is approximately 2 times larger than other process-based models (model 1-6 on Fig. 15). This pattern is partially because satellite inundated areas are $70 \%$ and $120 \%$ larger than the wetland extents (MF and AC) used in other models. Our tropical methane releases are also significantly higher than the other estimates shown, except for those of Walter et al. (2001) and Riley et al. (2011). These high emissions occur even though mean satellite inundated areas in the tropics are $37 \%$ and $45 \%$ lower than previous wetland extents (MF and $\mathrm{AC}$ ), indicating that the methane productivity in CLM4Me' is larger or oxidation is lower than other models. The higher tropical emissions in the current study may be partially attributed to the fact that CLM4CN overestimates gross primary production (GPP) and NPP over the tropical regions (Bonan et al., 2011). It is demonstrated at the Panama site (one of the tropical sites) that a more accurate NPP could improve model estimation against observation (Fig. 11a).
Note that CLM4Me (Riley et al., 2011) has comparable emissions in the tropics to the current study. At first glance this might not be surprising as the CLM4Me and CLM4Me' have approximately the same inundated areas and NPP in the tropics. However, the processes leading to these comparable emissions are quite different in the two models. The inclusion of $\mathrm{pH}$ in CLM4Me' (process not included in CLM4Me) lowers the tropical emissions by $41 \%$. In CLM4Me the emissions are comparable because using LAI in the calculation of aerenchyma (instead of FROOTC in CLM4Me') lowers the tropical emissions by $32 \%$ (see Sect. 4.10), while using a $\mathrm{Q}_{10}$ of 2 (instead of 3 as used in CLM4Me') lowers the tropical emissions by $22 \%$.

Seasonal variations of methane emissions in the tropics, temperate climatic zones, and northern latitudes generally follow the pattern of the inundated areas measured by satellite (Fig. 14a, b). This relationship occurs because satellite inundated areas were used to derive methane emissions in each grid cell. As can be seen in Fig. 14a, seasonal variations between south and north of the Equator have a different seasonality. Peak methane emissions occur in the rainy season, which is generally from June to October to the north of the Equator and from October to March to the south of the Equator. The seasonality of methane emissions in our model agrees well with that estimated in Cao et al. (1996) (their Fig. 3).

Even though our model simulated a low methane emission rate from northern latitudes $(>50 \mathrm{~N})$ in the summer, the seasonality of the satellite inundated areas is pronounced with maximum inundation in summer (Fig. 14b). The high inundated area in northern latitudes indicates that this region could potentially be a source of atmospheric methane that grows in importance because the duration and magnitude of methane production could increase as it experiences warming.

Note that, while the model includes the potential for methane emissions from non-inundated regions, the net emissions from non-inundated regions are small $(\sim$ 1.3 $\mathrm{Tg} \mathrm{CH}_{4} \mathrm{yr}^{-1}$ ), because most of the methane is oxidized in the soil profile above the water table.

We further evaluated methane emissions on the regional and global scales against atmospheric measurement by conducting simulations with the Community Atmospheric Model with chemistry (CAM-chem). Preliminary results suggest that our methane emission estimates in this study are within the current level of uncertainty in the methane budget and observations. Details of this preliminary analysis can be found in the supplementary document. Additionally, a sensitivity study using CLM modeled inundation for methane emissions is included in Appendix F. This study shows the importance of errors in hydrology for modeling methane, and supports the isolation of methane fluxes from errors in hydrology by using a satellite-derived hydrology when building the methane emission models. Other efforts are underway 
to improve the hydrology of the model (e.g., Swenson et al., 2012).

\subsection{Global simulation of rice paddies}

On average, our model estimates that global rice paddies emit approximately $42 \mathrm{Tg} \mathrm{CH}_{4} \mathrm{yr}^{-1}$ into the atmosphere, assuming no mid-season drainage. Our estimate is in the middle of current estimates of 26-120 $\mathrm{Tg} \mathrm{CH}_{4} \mathrm{yr}^{-1}$ (Fig. 13c) (Olivier et al., 2005; Bouwman, 1990; Cao et al., 1995; Yan et al., 2009; Chen and Prinn, 2006; Wuebbles and Hayhoe, 2002; Cao et al., 1998; Holzapfelpschorn and Seiler, 1986; Seiler et al., 1984; Scheehle et al., 2002; Sass, 1994). For instance, Cao et al. (1998) estimated global emissions from rice paddies to be $\sim 53 \mathrm{TgCH}_{4} \mathrm{yr}^{-1}$ using MF rice paddy areas. On the regional scale, CLM4Me' predicts $39 \mathrm{Tg} \mathrm{CH}_{4} \mathrm{yr}^{-1}$ is released from rice paddies in the Asian monsoon region (10S-50N, 65E-145E), which contributes $92 \%$ of the global rice paddy methane emissions (Fig. 14d). This estimate agrees well with the most recent study using LPJWHyMe global dynamical vegetation model forced with fractional rice cover compiled by Leff et al. (2004) (Spahni et al., 2011). Chinese rice paddies release more $\mathrm{CH}_{4}$ than from any other country. In our model, Chinese rice paddies released $\sim 10 \mathrm{TgCH}_{4} \mathrm{yr}^{-1}$, which is in the middle of other estimates $\left(7-17 \mathrm{Tg} \mathrm{CH}_{4} \mathrm{yr}^{-1}\right)$ derived using agricultural activity data and field measurements (Li et al., 2004; Matthews et al., 2000; Yan et al., 2009; Kai et al., 2010). For instance, Yan et al. (2009) estimated the methane emissions from Chinese rice paddies to be $7.41 \mathrm{Tg} \mathrm{CH}_{4} \mathrm{yr}^{-1}$ using the IPCC 2006 guidelines for national greenhouse gas inventories and methane emissions from rice paddies, and agricultural activity data for 2000. Yan et al. (2003) estimated emissions of $7.67 \mathrm{Tg} \mathrm{CH}_{4} \mathrm{yr}^{-1}$ in 1995 for China using measurements and region-specific $\mathrm{CH}_{4}$ emission factors. Recently, Kai et al. (2010) revised the Huang model (Huang et al., 1998) to include the effect of fertilizer use and water management and found that methane emissions from Chinese rice fields peaked in 1982 with an emission of $\sim 11 \mathrm{Tg} \mathrm{CH}_{4} \mathrm{yr}^{-1}$ in 2000. This estimate agrees with our estimates very well since we used the rice paddy fraction dataset developed by Portmann et al. (2010) for the year 2000.

Our model may overestimate methane emission from rice paddies for several reasons. First, we assumed continuous flooding during the growing season. Previous studies have suggested that mid-season drainages have been critical to reduce methane emissions in rice paddy fields. For instance, Yan et al. (2009) showed that one-time drainage in continuously flooded fields will reduce methane emissions by $4.1 \mathrm{Tg} \mathrm{CH}_{4} \mathrm{yr}^{-1}$ globally. Wassmann et al. (2000) suggested that mid-season drainage could reduce associated methane emissions by $7-80 \%$. On average, only about 30 $40 \%$ of rice paddies experience continuous flooding (Yan et al., 2009). Simulation with one time drainage in August in our model (not shown) decreased methane emissions by $6 \mathrm{Tg} \mathrm{CH}_{4} \mathrm{yr}^{-1}$ globally, or by about $14 \%$ of the total methane emissions from rice paddies. This reduction is similar to the findings in other studies (Yan et al., 2009). Secondly, the increases in inorganic fertilizer use since 1982 also have contributed to a reduction in methane emissions (Kai et al., 2010), a feature not currently present in the model. Finally, our assumed rice cultivation area includes some rainfed rice fields that might be only partially inundated. In order to accurately estimate rice paddy emissions, water management strategies (such as flooding and drainage), rice vegetation properties, and the use of fertilizers should be included in future methane models. Unfortunately, some of the required information is not readily available at the global scale.

\section{Summary and conclusions}

The purpose of this paper is to test several alternative parameterizations in CLM4Me, a global process-based biogeochemical methane model integrated with the Community Land Model version 4 (CLM4CN) (Riley et al., 2011), and to explicitly evaluate the model at the site level with measurements. To achieve this goal, we forced the model with inundated fraction derived from satellites and other environmental variables (e.g., pH). We also tested several physically meaningful changes to the model, including the $\mathrm{pH}$ control on methane production, the limitation of aerenchyma to plants in mostly inundated areas, and a parameterization of redox potential (included but not evaluated in CLM4Me). Site-level model comparisons to observations show that these changes improved the match between model simulations and observations at both wetland sites and rice paddies. We compiled data that allowed us to compare aerenchyma oxidation to simulations, and we used these data to adjust our maximum oxidation rate for sensitivity analysis. However, large sensitivities of the modeled emissions to other model parameters and sparse site-level observations make it difficult to be sure that these improvements are achieved via the right mechanisms. More data are needed to test alternative parameterization improvement options.

Our study suggests that models should be tested at the site level (not using global model simulations) when point measurements are used for evaluation. We only found limited data for tropical wetland methane fluxes, and unfortunately some datasets could not be used for the model evaluation exercise described here. For instance, many measurements on the Amazon Basin cover a large area for a short period of time (Bartlett et al., 1990; Devol et al., 1990) and therefore temporal analysis could not be obtained between model simulations and measurements at site levels.

With our base parameterization choices, our model simulates an average annual methane flux over the period 19932004 of $256 \mathrm{Tg} \mathrm{CH}_{4} \mathrm{yr}^{-1}$ (including soil sinks in inundated and uninundated areas) from natural wetlands. Our sensitivity analysis suggests a large range $\left(150-346 \mathrm{Tg} \mathrm{CH}_{4} \mathrm{yr}^{-1}\right)$. 
This estimate is at the high end of current estimates, although alternative parameter choices can substantially reduce this estimate. Tropical wetlands accounted for $79 \%$ of the global wetland methane budget. Northern latitudes $(>50 \mathrm{~N})$ contributed $12 \mathrm{Tg} \mathrm{CH}_{4} \mathrm{yr}^{-1}$, partially due to the low inundated area derived from satellites and the low high-latitude productivity in CLM4CN. This lower estimate of northern latitudes is consistent with isotopic constraints and some recent inverse modeling studies and bottom-up studies (e.g., Chen and Prinn, 2006; Denman et al., 2007; Kim et al., 2011; Bachand et al., 1996), but not others (Bloom et al., 2010; Bergamaschi et al., 2009; Bousquet et al., 2006). On average, $15 \%$ of methane was oxidized in the rhizosphere before being released to the atmosphere through aerenchyma. This proportion varied from region to region and was highest in middle latitudes.

We applied the set of changes enumerated above to global model simulations and conducted sensitivity analysis to test their importance in constraining global methane fluxes. More sensitivity studies were conducted in a related paper (Riley et al., 2011). Of the parameters tested here, sensitivity analysis suggests that global methane fluxes are most sensitive to the inclusion of a soil $\mathrm{pH}$ factor $\left(f_{\mathrm{pH}}\right)$. Sensitivity analysis suggests a large range $\left(150-346 \mathrm{Tg} \mathrm{CH}_{4} \mathrm{yr}^{-1}\right)$ in the annual methane flux when some of the features described in this study were not taken into account (Table 7).

Rice paddies were simulated to release $42 \mathrm{Tg} \mathrm{yr}^{-1}$ to the atmosphere. This estimate is within the range of current estimates. In our model, Chinese rice paddies contribute $10 \mathrm{Tg} \mathrm{CH}_{4} \mathrm{yr}^{-1}$, which is similar to other estimates using localized data. Due to the lack of information on agricultural activities (such as water management strategies and use of fertilizers) on the global scale, CLM4Me' might overestimate emissions from rice paddies. In addition, our rain-fed rice paddies might include upland and deepwater rice areas that are probably not significant sources of atmospheric methane.

This study represents an effort to quantify global methane fluxes. However, there are still large uncertainties on the magnitude of global methane fluxes (Petrescu et al., 2010). In order to remove these uncertainties, further model improvement should focus on constraining the parameters that govern methane-related processes and possibly employ spatially variable parameters (such as $Q_{10}$ for methane production). In addition, additional field measurements and studies of methane flux should focus on tropical wetlands; although tropical wetlands represent a significant source of atmospheric methane, and seasonal and interannual variation of methane flux is primarily controlled by the tropical wetland extent, relatively few field studies have been done in this region. This study also suggests that rhizospheric methane oxidation is an important control on the global methane flux. Rhizospheric methane oxidation is affected not only by environmental factors, but also by physiological factors. Detailed

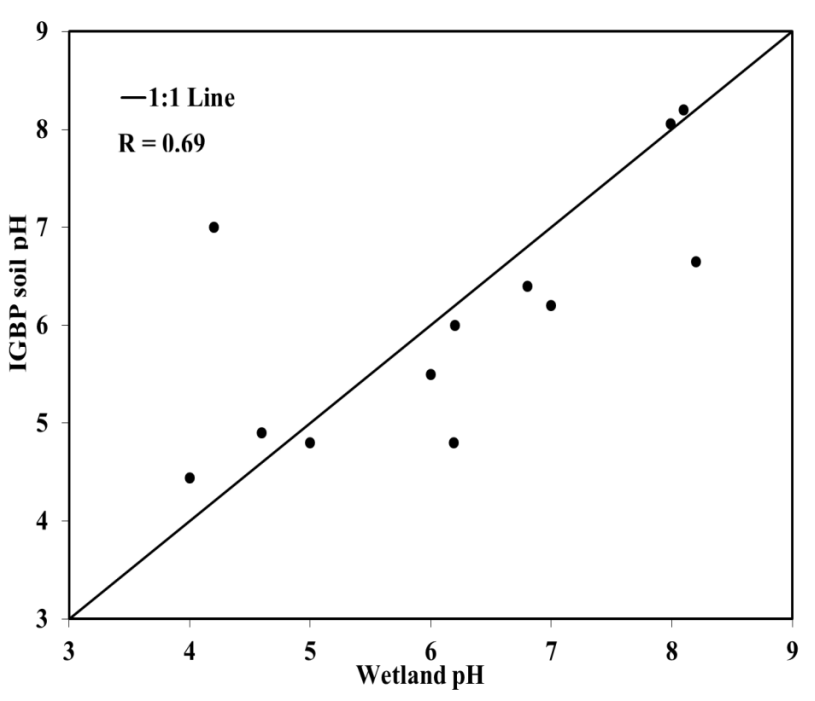

Fig. A1. Comparison between wetland $\mathrm{pH}$ and IGBP soil $\mathrm{pH}$.

study of this process is necessary to further improve global methane flux estimates.

\section{Appendix A}

\section{IGBP soil pH vs. wetland pH}

We compared wetland $\mathrm{pH}$ and IGBP soil $\mathrm{pH}$ at each site in this study (Fig. A1). It suggests a generally good agreement between the two different datasets ( $r=0.69$, RMSE $=1.07$ ).

\section{Appendix B}

\section{Spring peaks in methane emissions}

Aerenchyma in plants serves as a conduit for (i) $\mathrm{O}_{2}$ from the atmosphere to the soil and (ii) $\mathrm{CH}_{4}$ from the soil to the atmosphere. Aerenchyma might represent a larger pathway to the atmosphere than ebullition and diffusion in water when the total aerenchyma-specific area is large (see Fig. 7 in Riley et al., 2011). In this model, the specific aerenchyma area $T\left(\mathrm{~m}^{2} \mathrm{~m}^{-2}\right)$ depends on fine root C (FROOTC, $\mathrm{gC}$ $\mathrm{m}^{-2}$ ). Thus, FROOTC will affect the partitioning of methane fluxes among diffusion, ebullition, and transport through aerenchyma. So, accurate estimation of FROOTC plays a critical role in methane emissions.

Model simulations demonstrated an early spring spike in methane emissions at the Michigan site (Fig. B1a) lasting 2-3 days. This high methane flux was produced through the initial accumulation of methane in soils (Fig. B1c) followed by its rapid release through aerenchyma. Methane accumulates in the soil as methane production begins in the spring and upward transport is slow since aerenchyma, ebullition, 

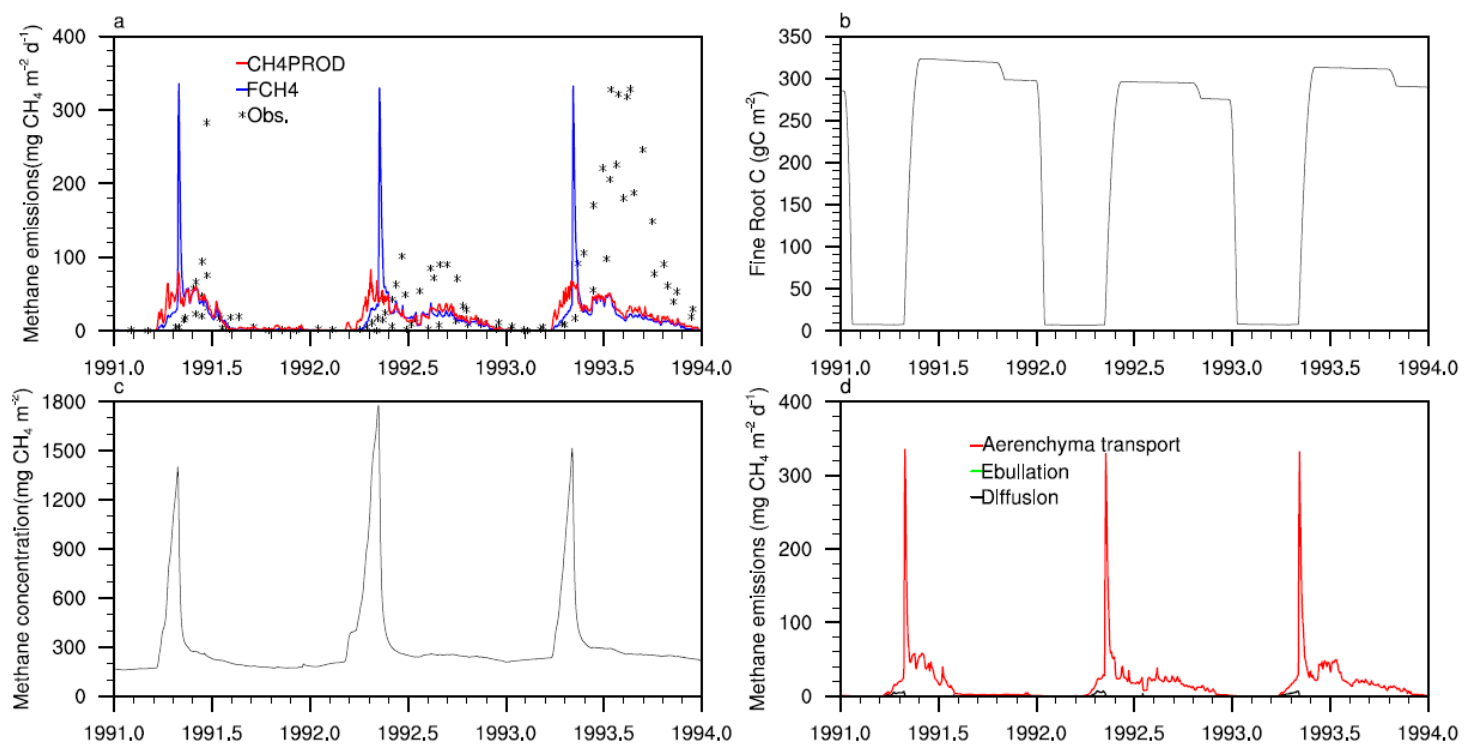

Fig. B1. Model simulations at the Michigan site (Shannon and White, 1994). (a) Model-simulated emission rates and production rates vs. observations; (b) model-simulated fine root carbon; (c) vertially averaged methane concentration in the model; (d) partition of methane fluxes through aerenchyma transport (red), ebullition (green), and surface diffusion (black).

and diffusion are slow (Fig. B1d). A sharp increase in aerenchyma releases methane in a burst because of abrupt increases in the simulated FROOTC, which increase from $\sim 0$ to highest values $(\sim 300)$ within $\sim 15$ days (Fig. B1b). Although it appears that this peak in $\mathrm{CH}_{4}$ emissions does not match the observations, we caution that weekly observations could easily miss these emissions, and that flux chamber observations are notoriously unable to capture temporally and spatially heterogeneous fluxes. This quick increase in fine root $\mathrm{C}$ predicted by the CLM-CN might not be realistic and deserves further attention for model testing and improvement.

\section{Appendix C}

\section{Simulated daily mean fluxes with (and without) pH function vs. observations}

Here we only selected the sites with $\mathrm{pH}<5$ or $\mathrm{pH}>8$ for this analysis, because other sites have optimal (or close to optimal) $\mathrm{pH}$ values and the inclusion of $\mathrm{pH}$ in methane production will not significantly affect their methane fluxes. As can be seen in Fig. $\mathrm{C}$, $\mathrm{pH}$ function generally decreases RMSE (from 472 to $143 \mathrm{mg} \mathrm{CH}_{4} \mathrm{~m}^{-2} \mathrm{~d}^{-1}$ ) and does not affect the correlations very much.

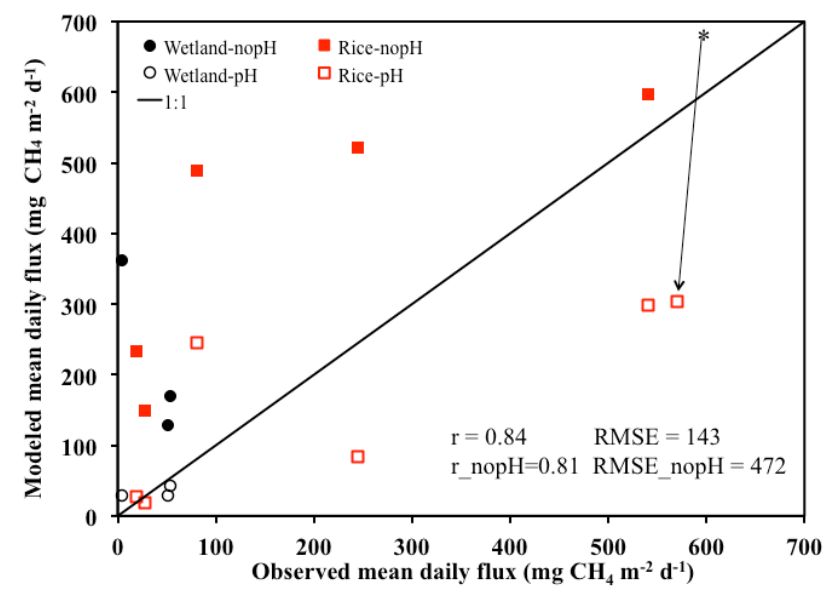

Fig. C1. Scatter plot of modeled mean daily flux with (and without) $\mathrm{pH}$ function with observations. ${ }^{*}$ indicates that the corresponding modeled mean daily flux without $\mathrm{pH}$ function at this site is $1601 \mathrm{mg} \mathrm{CH}_{4} \mathrm{~m}^{-2} \mathrm{~d}^{-1}$, which is beyond the range and not shown in this figure. Because of the limited wetland sites (only 3 ), we used both wetland and rice paddy sites together to calculate the correlations and RMSE. A detailed analysis of these three wetland sites is provided in Sect. 4.3 .

\section{Appendix D}

\section{Water table levels in the non-inundated fraction}

We assumed that water table level $(z)$ in the non-inundated fraction is strongly correlated with inundated fraction in each 


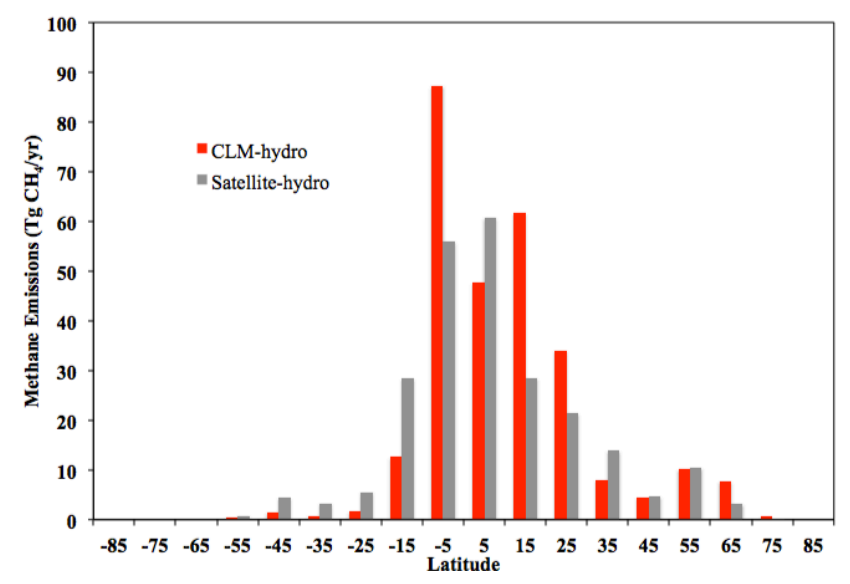

Fig. D1. Latitudinal distribution of methane emissions simulated in the CLM. CLM-hydro indicates simulations with CLM-derived hydrology (i.e., fully coupled with CLM hydrology), while Satellitehydro used satellite inundated fraction to drive methane model. CLM-hydro estimated a peak of methane emissions in the Southern Hemisphere, and Satellite-hydro produced maximum methane emissions in the Northern Hemisphere.

grid cell. Therefore, we calculated $z$ as

$z=-\frac{1}{C s^{*} f} \log \frac{f_{\text {inundated }}}{f_{\text {max }}}$

where $f_{\text {inundated }}$ is the satellite inundated fraction, $f_{\max }$ is the maximum inundated fraction. $C s$ and $f$ are two spatial variables used in Niu et al. (2005).

\section{Appendix E}

\section{Soil layers in the Community Land Model (CLM4)}

The soil column in CLM4 is discretized into 15 layers where the depth of soil layer $\mathrm{i}, z_{i}(\mathrm{~m})$, is

$z_{i}=f_{s}\{\exp [0.5(i-0.5)]-1\}$

where $f_{s}=0.025$ is a scaling factor. Therefore, the thickness of each layer $\Delta \mathrm{z}_{i}(\mathrm{~m})$ is

$\Delta z_{i}= \begin{cases}0.5\left(z_{1}+z_{2}\right) & i=1 \\ 0.5\left(z_{i+1}-z_{i-1}\right. & i=2,3, \ldots 14 \\ z_{15}-z_{14} & i=15\end{cases}$

The hydrology is calculated only over the top ten layers, and the bottom 5 layers are specified as bedrocks.

\section{Appendix F}

\section{Comparison of methane emissions using different hydrology}

CLM4Me/ can estimate methane emissions using satellite inundation data or its own inundation predicted by CLM hydrology. To see the impact of different hydrology (i.e., inundated area) on distribution of methane emissions, we compared the latitudinal distribution of methane emissions in the two simulations with different hydrology in Fig. D1. There are some notable differences between these two simulations. CLM-hydro estimated maximum methane emissions from the south of the Equator, while Satellite-hydro predicted relatively higher methane emissions from the north of the Equator. CLM-hydro also has much higher emissions from the latitude band 10-20, almost twice the amount of emissions in Satellite-hydro simulations. These differences suggest that hydrology, particularly the distribution of the inundated area, has large impacts on the spatial patterns of methane emissions.

\section{Supplementary material related to this article is available online at: http://www.biogeosciences.net/9/ 2793/2012/bg-9-2793-2012-supplement.pdf.}

Acknowledgements. We would like to thank Catherine Prigent for providing the global inundation dataset. We also thank Hidenori Takahashi for providing hydrological data for the Indonesia site used in this study. This work was supported by the National Science Foundation under Contract No. NSF 1049033 and the Department of Energy under Contract No. DE-SC0006791.

Edited by: F. Joos

\section{References}

Aselmann, I. and Crutzen, P. J.: Global Distribution of Natural Fresh-Water Wetlands and Rice Paddies, Their Net Primary Productivity, Seasonality and Possible Methane Emissions, J. Atmos. Chem., 8, 307-358, 1989.

Bachand, R., Moore, T. R., and Roulet, N. T.: A map of methane emissions from wetlands in Canada, Report 96-7, Centre for Climate and Global Change Research, McGill University, Montreal, 1996.

Baird, A. J., Beckwith, C. W., Waldron, S., and Waddington, J. M.: Ebullition of methane-containing gas bubbles from nearsurface Sphagnum peat, Geophy. Res. Letters, 31, L21505, doi:10.1029/2004GL021157, 2004.

Bartlett, K. B., Crill, P. M., Bonassi, J. A., Richey, J. E., and Harriss, R. C.: Methane flux from theAmazon River floodplain: Emissions during rising water, J. Geophys. Res., 95, 16773-16788, 1990.

Bartlett, K. B. and Harriss, R. C.: Review and Assessment of Methane Emissions from Wetlands, Chemosphere, 26, 261-320, 1993. 
Bergamaschi, P., Frankenberg, C., Meirink, J. F., Krol, M., Dentener, F., Wagner, T., Platt, U., Kaplan, J. O., Heimann, M., Dlugokencky, E. J., and Goede, A.: Satellite chartography of atmospheric methane from SCIAMACHY on board ENVISAT: 2. Evaluation based on inverse model simulations, J. Geophys. Res., 112, D02304, doi:02310.01029/02006JD007268, 2007.

Bergamaschi, P., Frankenberg, C., Meirink, J. F., Krol, M., Villani, M. G., Houweling, S., Dentener, F., Dlugokencky, E. J., Miller, J. B., Gatti, L. V., Engel, A., and Levin, I.: Inverse modeling of global and regional $\mathrm{CH} 4$ emissions using SCIAMACHY satellite retrievals, J. Geophys. Res.-Atmos., 114, D22301, doi:10.1029/2009JD012287, 2009.

Bloom, A. A., Palmer, P. I., Fraser, A., Reay, D. S., and Frankenberg, C.: Large-Scale Controls of Methanogenesis Inferred from Methane and Gravity Spaceborne Data, Science, 327, 322-325, doi:10.1126/science.1175176, 2010.

Bonan, G. B., Lawrence, P. J., Oleson, K. W., Levis, S., Jung, M., Reichstain, M., Lawrence, D. M., and Swenson, S. C.: Improving canopy processes in the Community Land Model (CLM4) using global flux fields empirically inferred from FLUXNET data, J. Geophys. Res., 116, G02014, doi:10.1029/2010JG001593, 2011.

Bousquet, P., Ciais, P., Miller, J. B., Dlugokencky, E. J., Hauglustaine, D. A., Prigent, C., Van der Werf, G. R., Peylin, P., Brunke, E. G., Carouge, C., Langenfelds, R. L., Lathiere, J., Papa, F., Ramonet, M., Schmidt, M., Steele, L. P., Tyler, S. C., and White, J.: Contribution of anthropogenic and natural sources to atmospheric methane variability, Nature, 443, 439443, doi:10.1038/Nature05132, 2006.

Bouwman, A. F.: Soils and the Greenhouse Effect, Wiley, Chicester, UK, 1990.

Butterbach-Bahl, K., Papen, H., and Rennenberg, H.: Impact of gas transport through rice cultivars on methane emission from rice paddy fields, Plant Cell Environ., 20, 1175-1183, 1997.

Cao, M., Dent, J. B., and Heal, O. W.: Modeling methane emissions from rice paddies, Glob. Biogeochem. Cy., 9, 183-195, 1995.

Cao, M., Marshall, S., and Gregson, K.: Global carbon exchange and methane emissions from natural wetlands: Application of a process-based model, J. Geophys. Res., 101, 14399-14414, 1996.

Cao, M., Gregson, K., and Marshall, S.: Global methane emission from wetlands and its sensitivity to climate change, Atmos. Environ., 32, 3293-3299, 1998.

Chappellaz, J., Blunier, T., Kints, S., Dallenbach, A., Barnola, J., Schwander, J., Raynaud, D., and Stauffer, B.: Changes in the atmospheric $\mathrm{CH}_{4}$ gradient between Greenland and Antarctica during the Holocene, J. Geophys. Res., 102, 15987-15997, 1997.

Chen, Y. H. and Prinn, R. G.: Estimation of atmospheric methane emissions between 1996 and 2001 using a three-dimensional global chemical transport model, J. Geophys. Res.-Atmos., 111, D10307, doi:10310.11029/12005JD006058, 2006.

Cheng, W., Yagi, K., Akiyama, H., Nishimura, S., Sudo, S., Fumoto, T., Hasegawa, T., Hartley, A. E., and Megonigal, J. P.: An empirical model of soil chemical properties that regulate methane production in Japanese rice paddy soils, J. Environ. Quality, 36, 1920-1925, doi:10.2134/Jeq2007.0201, 2007.

Christensen, T. R., Prentice, I. C., Kaplan, J., Haxeltine, A., and Sitch, S.: Methane flux from northern wetlands and tundra, Tellus, 48B, 652-661, 1996.
Cicerone, R. J. and Shetter, J. D.: Sources of Atmospheric Methane - Measurements in Rice Paddies and a Discussion, J. Geophys. Res.-Oceans Atmos., 86, 7203-7209, 1981.

Cicerone, R. J., Shetter, J. D., and Delwiche, C. C.: SeasonalVariation of Methane Flux from a California Rice Paddy, J. Geophys. Res.-Oceans Atmos., 88, 1022-1024, 1983.

Cicerone, R. J., Delwiche, C. C., Tyler, S. C., and Zimmerman, P. R.: Methane emissions from California rice paddies with varied treatments, Glob. Biogeochem. Cy., 6, 233-248, 1992.

Colmer, T. D.: Long-distance transport of gases in plants: a perspective on internal aeration and radial oxygen loss from roots, Plant Cell Environ., 26, 17-36, 2003.

Conrad, R. and Schutz, H.: Methods of studying methanogenic bacteria and methanogenic activities in aquatic environments, in: Methods in Aquatic Bacteriology, edited by: Austin, B., Wiley, Chichester, 301-343, 1988.

Conrad, R.: Control of microbial methane production in wetland rice fields, Nutr. Cyc. Agroecosyst., 64, 59-69, 2002.

Daugherty, C. J., Matthews, S. W., and Musgrave, M. E.: Structural changes in rapid-cycling Brassica rapa selected for differential water-logging tolerance, Canadian J. Botany, 72, 1322-1328, 1994.

Denman, K. L., Brasseur, G., Chidthaisong, A., Ciais, P., Cox, P. M., Dickinson, R. E., Hauglustaine, D., Heinze, C., Holland, E., Jacob, D., Lohmann, U., Ramachandran, S., da Silva Dias, P. L., Wofsy, S. C., and Zhang, X.: Couplings Between Changes in the Climate System and Biogeochemistry, in: Climate Change 2007: The Physical Science Basis. Contribution of Working Group I to the Fourth Assessment Report of the Intergovernmental Panel on Climate Change, edited by: Solomon, S., Qin, D., Manning, M., Chen, Z., Marquis, M., Averyt, K. B., Tignor, M., and Miller, H. L., Cambridge University Press, Cambridge, UK and New York, NY, USA, 2007.

Devol, A. H., Richey, J. E., Forsberg, B. R., and Martinelli, L. A.: Seasonal Dynamics in Methane Emissions from the Amazon River Floodplain to the Troposphere, J. Geophys. Res.-Atmos., 95, 16417-16426, 1990.

Dlugokencky, E. J., Houweling, S., Bruhwiler, L., Masarie, K. A., Lang, P. M., Miller, J. B., and Tans, P. P.: Atmospheric methane levels off: Temporary pause or a new steady-state?, J. Geophys. Res., 30, 1992, doi:10.1029/2003GL018126, 2003.

Dueck, T. A., Visser, R. D., Poorter, H., Persijn, S., Gorissen, A., Visser, W. D., Schapendonk, A., Verhagen, J., Snel, J., Harren, F. J. M., Ngai, A. K. Y., Verstappen, F., Bouwmeester, H., Voesenek, L. A. C. J., and Werf, A. V. D.: No evidence for substantial aerobic methane emission by terrestrial plants: a 13C-labelling approach, New Phytol., 175, 29-35, 2007.

Dunfield, P., Knowles, R., Dumont, R., and Moore, T. R.: Methane production and comsumption in temperate and subarctic peat soils: response to temperature and pH, Soil Biol. Biochem., 25, 321-326, 1993.

Etheridge, D., Steele, L., Francey, R., and Langenfelds, R.: Atmospheric methane between 1000 A.D. and present: evidence of anthropogenic emissions and climatic variability, J. Geophys. Res., 103, 15979-15993, 1998.

Fabbri, L. T., Rua, G. H., and Bartoloni, N.: Different patterns of aerenchyma formation in two hygrophytic species of Paspalum (Poaceae) as response to flooding, Flora, 200, 354-360, doi:10.1016/j.flora.2004.11.002, 2005. 
Finlayson, C. M., Davidson, N. C., Spiers, A. G., and Stevenson, N. J.: Global wetland inventory - current status and future priorities, Mar. Freshwater Res., 50, 717-727, 1999.

Frankenberg, C., Meirink, J. F., Bergamaschi, P., Goede, A. P. H., Heimann, M., Korner, S., Platt, U., Van Weele, M., and Wagner, T.: Satellite chartography of atmospheric methane from SCIAMACHY on board ENVISAT: Analysis of the years 2003 and 2004, J. Geophys. Res., 111, D07303, doi:07310.01029/02005JD006235, 2006.

Fung, I., John, J., Lerner, J., Matthews, E., Prather, M., Steele, L. P., and Fraser, P. J.: 3-Dimensional Model Synthesis of the Global Methane Cycle, J. Geophys. Res.-Atmos., 96, 13033 13065, 1991.

Grosse, W., Frye, J., and Lattermann, S.: Root Aeration in Wetland Trees by Pressurized Gas-Transport, Tree Physiol., 10, 285-295, 1992.

Hein, R., Crutzen, P. J., and Heimann, M.: An inverse modeling approach to investigate the global atmospheric methane cycle, Global Biogeochem. Cy., 11, 43-76, 1997.

Holzapfelpschorn, A. and Seiler, W.: Methane Emission during a Cultivation Period from an Italian Rice Paddy, J. Geophys. Res.Atmos., 91, 1803-1814, 1986.

Huang, Y., Sass, R. L., and Fisher, F. M.: A semi-empirical model of methane emission from flooded rice paddy soils, Glob. Change Biol., 4, 247-268, 1998.

Huang, Y., Jaing, J. Y., Zong, L. G., Sass, R. L., and Fisher, F. M.: Comparison of field measurements of $\mathrm{CH} 4$ emission from rice cultivation in Nanjing, China and in Texas, USA, Adv. Atmos. Sci., 18, 1121-1130, 2001.

IPCC: Climate Change 2007: Synthesis Report, Contribution of Working Groups I, II and III to the Fourth Assessment Report of the Intergovernmental Panel on Climate Change, edited by: Pachauri, R. K and Reisinger, A. Core Writing Team, IPCC, Geneva, Switzerland, 104 pp., 2007.

Jain, M. C., Kumar, S., Wassmann, R., Mitra, S., Singh, S. D., Singh, J. P., Singh, R., Yadav, A. K., and Gupta, S.: Methane emissions from irrigated rice fields in northern India (New Delhi), Nutrient Cyc. Agroecosys., 58, 75-83, 2000.

Jauhiainen, J., Takahashi, H., Heikkinen, J. E. P., Martikainen, P. J., and Vasander, H.: Carbon fluxes from a tropical peat swamp forest floor, Global Change Biol., 11, 1788-1797, 2005.

Jiang, C. S., Wang, Y. S., Zheng, X. H., Zhu, B., Huang, Y., and Hao, Q. J.: Methane and nitrous oxide emissions from three paddy rice based cultivation systems in southwest China, Adv. Atmos. Sci., 23, 415-424, doi:10.1007/s00376-006-0415-5, 2006.

Kai, F. M., Tyler, S. C., and Randerson, J. T.: Modeling methane emissions from rice agriculture in China during 1961-2007, J. Integrative Environ. Sci., 7, 49-60, doi:10.1080/1943815X.2010.492227, 2010.

Keller, M. M.: Biological sources and sinks of methane in tropical habitats and tropical atmospheric chemistry, $\mathrm{PhD}$, Geological Geophys. Sci., Princeton University, 216 pp., 1990.

Kellner, E., Baird, A. J., Oosterwoud, M., Harrison, K., and Waddington, J. M.: Effect of temperature and atmospheric pressure on methane $\left(\mathrm{CH}_{4}\right)$ ebullition from near surface peats, Geophys. Res. Letters, 33, L18405, doi:10.1029/2006GL027509, 2006.

Kende, H., van der Knaap, E., and Cho, H. T.: Deepwater rice: A model plant to study stem elongation, Plant Physiol., 118, 1105-
1110, 1998.

Keppler, F., Hamilton, J. T. G., Brass, M., and Roeckmann, T.: Methane emissions from terrestrial plants under aerobic conditions, Nature, 439, 187-191, 2006.

Kim, H.-S., Maksyutov, S., Glagolev, M. V., Machida, T., Patra, P. K., Sudo, K., and Inoue, G.: Evaluation of methane emissions from West Siberian wetlands based on inverse modeling, Environ. Res. Lett., 6, doi:10.1088/1748-9326/6/3/035201, 2011.

Kirschbaum, M. U. F., Bruhn, D., Etheridge, D., Evans, J. R., Farquhar, G. D., Gifford, R. M., Paul, K. I., and Winters, A. J.: A comment on the quantitative significance of aerobic methane release by plants, Funct. Plant Biol., 33, 521-530, 2006.

Knoblauch, C.: Bodenkundlich-mikrobiologische Bestandsaufnahme zur Mehtanoxidation in einer Flubmarsch der Tide-Elbe, diploma thesis Univ. of Hamburg, Univ. of Hamburg, Hamburg, Germany, 1994.

Kolb, R. M. and Joly, C. A.: Flooding tolerance of Tabebuia cassinoides: Metabolic, morphological and growth responses, Flora, 204, 528-535, doi:10.1016/j.flora.2008.07.004, 2009.

Lawrence, D. M., Oleson, K. W., Flanner, M. G., Thornton, P. E., Swenson, S. C., Lawrence, P. J., Zeng, X., Yang, Z. L., Levis, S., Sakaguchi, K., Bonan, G. B., and Slater, A. G.: Parameterization improvements and functional and structural advances in version 4 of the Community Land Model, J. Adv. Model. Earth Sys., 3, M03001, 27 pp., doi:10.1029/2011MS000045, 2011.

Leff, B., Ramankutty, N., and Foley, J. A.: Geographic distribution of major crops across the world, Glob. Biogeochem. Cy., 18, GB1009, doi:10.1029/2003gb002108, 2004.

Li, C., Aber, J., Stange, F., Butterbach-Bahl, K., Papen, H.: A process-oriented model of $\mathrm{N}_{2} \mathrm{O}$ and $\mathrm{NO}$ emissions from forest soils: 1, Model development, J. Geophys. Res., 105, 4, 43694384, 2000.

Li, C. S., Mosier, A., Wassmann, R., Cai, Z., Zheng, X., Huang, Y., Tsuruta, H., Boonjawat, J., and Lantin, R.: Modeling greenhouse gas emissions from rice-based production systems: Sensitivity and upscaling, Glob. Biogeochem. Cy., 18, GB1043, doi:10.1029/2003GB002045, 2004.

Lidstrom, M. E. and Somers, L.: Seasonal study of methane oxidation in Lake Washington, Appl. Environ. Microbiol., 47, 12551260, 1984.

Lovley, D. R. and Phillips, E. J. P.: Competitive Mechanisms for Inhibition of Sulfate Reduction and Methane Production in the Zone of Ferric Iron Reduction in Sediments, Appl. Environ. Microbiol., 53, 2636-2641, 1987.

Magdoff, F. R. and Bartlett, R. J.: Soil-Ph Buffering Revisited, Soil Sci. Soc. Am. J., 49, 145-148, 1985.

Matthews, E. and Fung, I.: Methane emission from natural wetlands: Global distribution, area, and environmental characteristics of sources, Glob. Biogeochem. Cy., 1, 61-86, 1987.

Matthews, R. B., Wassmann, R., Buendia, L. V., and Knox, J. W.: Using a crop/soil simulation model and GIS techniques to assess methane emissions from rice fields in Asia. Part II. Model validation and sensitivity analysis, Nutrient Cyc. Agroecosys., 58, 161-177, doi:10.1023/A:1009846703516, 2000.

Mikaloff Fletcher, S. E., Tans, P. P., Bruhwiler, L. M., Miller, J. B., and Heimann, M.: CH4 sources estimated from atmospheric observations of $\mathrm{CH} 4$ and its $13 \mathrm{C} / 12 \mathrm{C}$ isotopic ratios: 2 . Inverse modeling of $\mathrm{CH} 4$ fluxes from geographical regions, Glob. Biogeochem. Cy., 18, GB4005, doi:4010.1029/2004GB002224, 
2004.

Minami, K.: Effects of agricultural management on methane esmission from rice paddies, Natl. Inst. Agro-Environ. Sci., Tsukuba, Japan, 1989.

Nahlik, A. M. and Mitsch, W. J.: Methane emissions from tropical freshwater wetlands located in different climatic zones of Costa Rica, Global Change Biol., 17, 1321-1334, doi:10.1111/j.13652486.2010.02190.x, 2011.

Neue, H.-U., Becker-Heidmann, P., and Scharpenseel, H. W.: Organic matter dynamics, soil properties, and cultural practices in rice lands and their relationship to methane in: Soils and the Greenhouse Effect, edited by: Bouwman, A. F., John Wiley, New York, 457-466, 1990.

Niu, G. Y., Yang, Z. L., Dickinson, R. E., and Gulden, L. E.: A simple TOPMODEL-based runoff parameterization (SIMTOP) for use in global climate models, J. Geophys. Res., 110, D21106, doi:21110.21029/22005JD006111, 2005.

Nouchi, I., Mariko, S., and Aoki, K.: Mechanism of Methane Transport from the Rhizosphere to the Atmosphere through Rice Plants, Plant Physiol., 94, 59-66, 1990.

Nugroho, S. G., Lumbanraja, J., Suprapto, H., Sunyoto, W. S. A., Haraguchi, H., and Kimura, M.: Methane Emission from an Indonesian Paddy Field Subjected to Several Fertilizer Treatments, Soil Sci. Plant Nutrition, 40, 275-281, 1994.

Olivier, J. G. J., Van, A. J. A., Dentener, F. J., and Pagliari, V.: Recent trends in global greenhouse gas emissions: regional trends 1970-2000 and spatial distribution of key sources in 2000, Environ. Sci., 2, 81-99, 2005.

Page, S. E., Rieley, J. O., and Banks, C. J.: Global and regional importance of the tropical peatland carbon pool, Global Change Biol., 17, 798-818, doi:710.1111/j.1365-2486.2010.02279.x, 2011.

Papa, F., Prigent, C., Aires, F., Jimenez, C., Rossow, W. B., and Matthews, E.: Interannual variability of surface water extent at the global scale, 1993-2004, J. Geophys. Res.-Atmos., 115, D12111, doi:10.1029/2009JD012674, 2010.

Petrescu, A. M. R., van Beek, L. P. H., van Huissteden, J., Prigent, C., Sachs, T., Corradi, C. A. R., Parmentier, F. J. W., and Dolman, A. J.: Modeling regional to global CH4 emissions of boreal and arctic wetlands, Glob. Biogeochem. Cy., 24, GB4009, doi:4010.1029/2009gb003610, 2010.

Pleijsier, L. K.: Proceedings of an international workshop on the Laboratory Methods and Data Exchange programme. Technical Paper 13, ISRIC, Wageningen, 6-9, 1986.

Popp, T. J., Chanton, J. P., Whiting, G. J., and Grant, N.: Evaluation of methane oxidation in the rhizosphere of a Carex dominated fen in north central Alberta, Canada, Biogeochemistry, 51, 259-281, 2000.

Portmann, F. T., Siebert, S., and Doll, P.: MIRCA2000-Global monthly irrigated and rainfed crop areas around the year 2000: A new high-resolution data set for agricultural and hydrological modeling, Global Biogeochem. Cy., 24, GB1011, doi:10.1029/2008GB003435, 2010.

Potter, C. S.: An ecosystem simulation model for methane production and emission from wetlands, Glob. Biogeochem. Cy., 11, 495-506, 1997.

Prigent, C., Papa, F., Aires, F., Rossow, W. B., and Matthews, E.: Global inundation dynamics inferred from multiple satellite observations, 1993-2000, J. Geophys. Res.-Atmos., 112, D12107,
doi:10.1029/2006JD007847, 2007.

Qian, T. T., Dai, A., Trenberth, K. E., and Oleson, K. W.: Simulation of global land surface conditions from 1948 to 2004. Part I: Forcing data and evaluations, J. Hydrometeorol., 7, 953-975, 2006.

Randerson, J., Hoffman, F., Thornton, P., Mahowald, N., Lindsay, K., Lee, Y.-H., Nevison, C. D., Doney, S., Bonan, G., Stockli, R., Covey, C., Running, S., and Fung, I.: Systematic assessment of terrestrial biogeochemistry in coupled climate-carbon models, Global Change Biol., 15, 2462, doi:2410.1111/j.13652486.2009.01912x, 2009.

Rigby, M., Prinn, R. G., Fraser, P. J., Simmonds, P. G., Langenfelds, R. L., Huang, J., Cunnold, D. M., Steele, L. P., Krummel, P. B., Weiss, R. F., O’Doherty, S., Salameh, P. K., Wang, H. J., Harth, C. M., Mühle, J., and Porter, L. W.: Renewed growth of atmospheric methane, Geophy. Res. Lett., 35, L22805, doi:10.1029/2008GL036037, 2008.

Riley, W. J., Subin, Z. M., Lawrence, D. M., Swenson, S. C., Torn, M. S., Meng, L., Mahowald, N. M., and Hess, P.: Barriers to predicting changes in global terrestrial methane fluxes: analyses using CLM4Me, a methane biogeochemistry model integrated in CESM, Biogeosciences Discuss., 8, 1733-1807, doi:10.5194/bgd-8-1733-2011, 2011.

Ringeval, B., de Noblet-Ducoudre, N., Ciais, P., Bousquet, P., Prigent, C., Papa, F., and Rossow, W. B.: An attempt to quantify the impact of changes in wetland extent on methane emissions on the seasonal and interannual time scales, Glob. Biogeochem. Cy., 24, GB2003, doi:10.1029/2008gb003354, 2010.

Rydin, H. and Jeglum, J.: The Biology of Peatlands, Oxford University Press, 360 pp., 2006.

Saarnio, S., Alm, J., Silvola, J., Lohila, A., Nykanen, H., and Martikainen, P. J.: Seasonal variation in $\mathrm{CH} 4$ emissions and production and oxidation potentials at microsites on an oligotrophic pine fen, Oecologia, 110, 414-422, 1997.

Sass, R. L.: Short summary chapter for methane, in: CH4 and N2O:Global Emissions and Controls from Rice Fields and other Agricultural and Industrial Sources, edited by: Minami, K., Mosier, A., and Sass, R. L., Natl. Inst. of Agro-Environ. Sci., Tsukuba, Japan, 1-7, 1994.

Scheehle, E. A., Irving, W. N., and Kruger, D.: Global anthropogenic methane emission, in: Non- $\mathrm{CO}_{2}$ Greenhouse Gases, edited by: Van Ham, J. A. P. B., Guicherit, R., and WilliamsJacobse, J., Millpress, Rottendam, 257-262, 2002.

Segers, R.: Methane Production and Methane Consumption: A Review of Processes Underlying Wetland Methane Fluxes, Biogeochemistry, 41, 23-51, 1998.

Seiler, W., Holzapfelpschorn, A., Conrad, R., and Scharffe, D.: Methane Emission from Rice Paddies, J. Atmos. Chem., 1, 241268, 1984.

Setyanto, P., Rosenani, A. B., Boer, R., Fauziah, C. I., and Khanif, M. J.: The effect of rice cultivars on methane emission from irrigated rice field, Indonesian J. Agricultural Sci., 5, 20-31, 2004.

Shannon, R. D. and White, J. R.: 3-Year Study of Controls on Methane Emissions from 2 Michigan Peatlands, Biogeochemistry, 27, 35-60, 1994.

Shurpali, N. J. and Verma, S. B.: Micrometeorological measurements of methane flux in a Minnesota peatland during two growing seasons, Biogeochemistry, 40, 1-15, 1998. 
Sigren, L. K., Lewis, S. T., Fisher, F. M., and Sass, R. L.: Effects of field drainage on soil parameters related to methane production and emission from rice paddies, Glob. Biogeochem. Cy., 11, 151-162, 1997.

Spahni, R., Wania, R., Neef, L., van Weele, M., Pison, I., Bousquet, P., Frankenberg, C., Foster, P. N., Joos, F., Prentice, I. C., and van Velthoven, P.: Constraining global methane emissions and uptake by ecosystems, Biogeosciences, 8, 1643-1665, doi:10.5194/bg8-1643-2011, 2011.

Strack, M., Kellner, E., and Waddington, J. M.: Dynamics of biogenic gas bubbles in peat and their effects on peatland biogeochemistry, Glob. Biogeochem. Cy., 19, GB1003, doi:10.1029/2004gb002330, 2005.

Swenson, S. C., Lawrence, D. M., and Lee, H.: Improved Simulation of the Terrestrial Hydrological Cycle in Permafrost Regions by the Community Land Model, J. Adv. Model. Earth Sys., in review, 2012.

Tempel, P., Batjes, N. H., and van Engelen, V. W. P.: IGBP-DIS soil data set for pedotransfer function development, Working paper and Preprint 96/05, International Soil Reference and Information Center (ISRIC), Wageningen, 1966.

Valentine, D. W., Holland, E. A., and Schimel, D. S.: Ecosystem and physiological controls over methane production in northern wetlands, J. Geophys. Res., 99, 1563-1571, 1994.

van Bodegom, P. M. and Stams, A. J. M.: Effects of alternative electron acceptors and temperature on methanogenesis in rice paddy soils, Chemosphere, 39, 167-182, 1999.

van der Nat, F. J. W. A. and Middelburg, J. J.: Seasonal variation in methane oxidation by the rhizosphere of Phragmites australis and Scirpus lacustris, Aquatic Bot., 61, 95-110, 1998.

Voesenek, L. A. C. J. and Blom, C. W. P. M.: Growth responses of Rumex species in relation to submergence and ethylene, Plant Cell Environ., 12, 433-439, 1989.

Voesenek, L. A. C. J., Armstrong, W., Colmer, T. D., Bögemann, G. M. and McDonald, M. P.: A lack of aerenchyma and high rates of radial oxygen from the root base contribute to the water-logging intolerance of Brassica napus, Australian J. Plant Physiol., 26, 87-93, 1999.

Walter, B. P. and Heimann, M.: A process-based, climate-sensitive model to derive methane emissions from natural wetlands: Application to five wetland sites, sensitivity to model parameters, and climate, Glob. Biogeochem. Cy., 14, 745-765, 2000

Walter, B. P., Heimann, M., and Matthews, E.: Modeling modern methane emissions from natural wetlands 1 . Model description and results, J. Geophys. Res.-Atmos., 106, 34189-34206, 2001.

Walter, K. M., Zimov, S. A., Chanton, J. P., Verbyla, D., and Chapin, F. S.: Methane bubbling from Siberian thaw lakes as a positive feedback to climate warming, Nature, 443, 71-75, doi:10.1038/nature05040, 2006.

Wang, Z. P., DeLaune, R. D., Masscheleyn, P. H., and Patrick, W. H. J.: Soil redox and $\mathrm{pH}$ effects on methane production in a flooded rice soil, Soil Sci. Soc. Am. J., 57, 386-391, 1993.
Wania, R., Ross, I., and Prentice, I. C.: Implementation and evaluation of a new methane model within a dynamic global vegetation model: LPJ-WHyMe v1.3, Geosci. Model Dev., 3, 565-584, doi:10.5194/gmd-3-565-2010, 2010.

Wassmann, R., Neue, H. U., Lantin, R. S., Aduna, J. B., Alberto, M C. R., Andales, M. J., Tan, M. J., Vandergon, H. A. C. D., Hoffmann, H., Papen, H., Rennenberg, H., and Seiler, W.: Temporal Patterns of Methane Emissions from Wetland Rice Fields Treated by Different Modes of N-Application, J. Geophys. Res.-Atmos., 99, 16457-16462, 1994.

Whalen, S. C.: Biogeochemistry of methane exchange between natural wetlands and the atmosphere, Environ. Eng. Sci., 22, 73-94, 2005.

Whiting, G. J. and Chanton, J. P.: Control of the diurnal pattern of methane emission from emergent aquatic macrophytes by gas transport mechanisms, Aquatic Bot., 54, 237-253, 1996.

Williams, R. T. and Crawford, R. L.: Methanogenic bacteria, including an acid-tolerant strain, from petalands, Appl. Environ. Microbiol., 50, 1542-1544, 1985.

Wuebbles, D. J. and Hayhoe, K.: Atmospheric methane and global change, Earth-Sci. Rev., 57, 177-210, 2002

Yagi, K., Tsuruta, H., Kanda, K., and Minami, K.: Effect of water management on methane emission from a Japanese rice paddy field: Automated methane monitoring, Glob. Biogeochem. Cy., 10, 255-267, 1996.

Yan, X. Y., Ohara, T., and Akimoto, H.: Development of regionspecific emission factors and estimation of methane emission from rice fields in the East, Southeast and South Asian countries, Glob. Change Biol., 9, 237-254, 2003.

Yan, X., Akiyama, H., Yagi, K., and Akimoto, H.: Global estimations of the inventory and mitigation potential of methane emissions from rice cultivation conducted using the 2006 Intergovernmental Panel on Climate Change Guidelines, Glob. Biogeochem. Cy., 23, GB2002, doi:10.1029/2008GB003299, 2009.

Zehnder, A. J. B. and Stumm, W.: Geochemistry and biogeochemistry of anaerobic habitats, in: Anaerobic Microbiol, edited by: Zehnder, A. J. B., Wiley, New York, 1-38, 1988.

Zhang, Y., Li, C. S., Trettin, C. C., Li, H., and Sun, G.: An integrated model of soil, hydrology, and vegetation for carbon dynamics in wetland ecosystems, Glob. Biogeochem. Cy., 16, 1061 , doi:10.1029/2001gb001838, 2002.

Zhao, M. S., Heinsch, F. A., Nemani, R. R., and Running, S. W.: Improvements of the MODIS terrestrial gross and net primary production global data set, Remote Sens. Environ., 95, 164-176, doi:10.1016/j.rse.2004.12.011, 2005.

Zhuang, Q., Melillo, J. M., Kicklighter, D. W., Prinn, R. G., McGuire, A. D., Steudler, P. A., Felzer, B. S., and $\mathrm{Hu}$, S.: Methane fluxes between terrestrial ecosystems and the atmosphere at northern high latitudes during the past century: A retrospective analysis with a process-based biogeochemistry model, Glob. Biogeochem. Cy., 18, GB3010, doi:3010.1029/2004GB002239, 2004. 